University of Nebraska - Lincoln

DigitalCommons@University of Nebraska - Lincoln

\title{
Weathering of Sulfidic Shale and Copper Mine Waste: Secondary Minerals and Metal Cycling in Great Smoky Mountains National Park, Tennessee, and North Carolina, USA
}

Jane M. Hammarstrom

US Geological Survey, 954 National Center, Reston,VA, jhammars@usgs.gov

Robert R. Seal II

U.S. Geological Survey, 954 National Center, Reston, Virginia 20192, USA, rseal@usgs.gov

Allen L. Meier

US Geological Survey, Denver, CO 80225, USA

John C. Jackson

US Geological Survey, 954 National Center, Reston, VA

Follow this and additional works at: https://digitalcommons.unl.edu/usgsstaffpub

Part of the Earth Sciences Commons

Hammarstrom, Jane M.; Seal II, Robert R.; Meier, Allen L.; and Jackson, John C., "Weathering of Sulfidic Shale and Copper Mine Waste: Secondary Minerals and Metal Cycling in Great Smoky Mountains National Park, Tennessee, and North Carolina, USA" (2003). USGS Staff -- Published Research. 339.

https://digitalcommons.unl.edu/usgsstaffpub/339

This Article is brought to you for free and open access by the US Geological Survey at DigitalCommons@University of Nebraska - Lincoln. It has been accepted for inclusion in USGS Staff -- Published Research by an authorized administrator of DigitalCommons@University of Nebraska - Lincoln. 


\title{
Weathering of sulfidic shale and copper mine waste: secondary minerals and metal cycling in Great Smoky Mountains National Park, Tennessee, and North Carolina, USA
}

\author{
Jane M. Hammarstrom - Robert R. Seal II - Allen L. Meier · John C. Jackson
}

\begin{abstract}
Metal cycling via physical and chemical weathering of discrete sources (copper mines) and regional (non-point) sources (sulfide-rich shale) is evaluated by examining the mineralogy and chemistry of weathering products in Great Smoky Mountains National Park, Tennessee, and North Carolina, USA. The elements in copper mine waste, secondary minerals, stream sediments, and waters that are most likely to have negative impacts on aquatic ecosystems are aluminum, copper, zinc, and arsenic because these elements locally exceed toxicity guidelines for surface waters or for stream sediments. Acid-mine drainage has not developed in streams draining inactive copper mines. Acid-rock drainage and chemical weathering processes that accompany debris flows or human disturbances of sulfidic rocks are comparable to processes that develop acid-mine drainage elsewhere. Despite the high rainfall in the mountain range, sheltered areas and intermittent dry spells provide local venues for development of secondary weathering products that can impact aquatic ecosystems.
\end{abstract}

Electronic Supplementary Material Supplementary material is available for this article if you access the article at http://dx.doi.org/10.1007/s00254-003-0856-4. A link in the frame on the left on that page takes you directly to the supplementary material.

Received: 4 March 2003 / Accepted: 12 May 2003 Published online: 18 July 2003

(C) Springer-Verlag 2003

J. M. Hammarstrom $(\varangle) \cdot$ R. R. Seal II · J. C. Jackson US Geological Survey, 954 National Center, Reston, VA 20192, USA E-mail: jhammars@usgs.gov

Tel.: +1-703-6486165

Fax: +1-703-6486252

A. L. Meier

US Geological Survey, Denver, C0 80225, USA
Keywords Secondary minerals · Great Smoky Mountains National Park · Tennessee and North Carolina $\cdot$ Acid drainage

\section{Introduction}

Great Smoky Mountains National Park, an International Biosphere Reserve of southern Appalachian forest in Tennessee and North Carolina, is a natural laboratory for evaluating the role of weathering processes in cycling metals in surface environments. The park includes two inactive copper mines hosted by a regionally extensive carbonate-poor lithology that contains disseminated iron sulfide minerals (pyrite and pyrrhotite). Oxidative weathering of iron sulfide minerals typically produces acid-rock drainage. In addition to mining, a localized source of sulfide minerals, past road construction and natural debris flows contribute sediment to surface waters and expose fresh rock to weathering. Subsequent physical and chemical weathering contributes sediment, acidity, metals, and secondary precipitates to streams, rendering local watersheds inhospitable to aquatic biota. Impacts on fish, salamanders, and benthic invertebrates have been documented in the park (Huckabee and others 1975; Herrmann and others 1979; Trumpf and others 1979; Mathews and Morgan 1982; Kucken and others 1994). Variations in types of bedrock (calcareous vs pyritic) influence water quality in the park (Silsbee and Larson 1982; Flum and Nodvin 1995). Recent studies on the distribution of sulfidic rocks and inventories of prehistoric and historic debris flows that developed acid drainage are using geology to help interpret the distribution of flora and fauna in the area (Southworth and others 2001). Furthermore, the park experiences some of the highest rates of acid deposition from the atmosphere of any forested ecosystem in North America, which exacerbates surface water quality impacts from rock weathering. Most of the bedrock and regolith in the park lacks acid-neutralizing capacity (Flum and others 1997). 


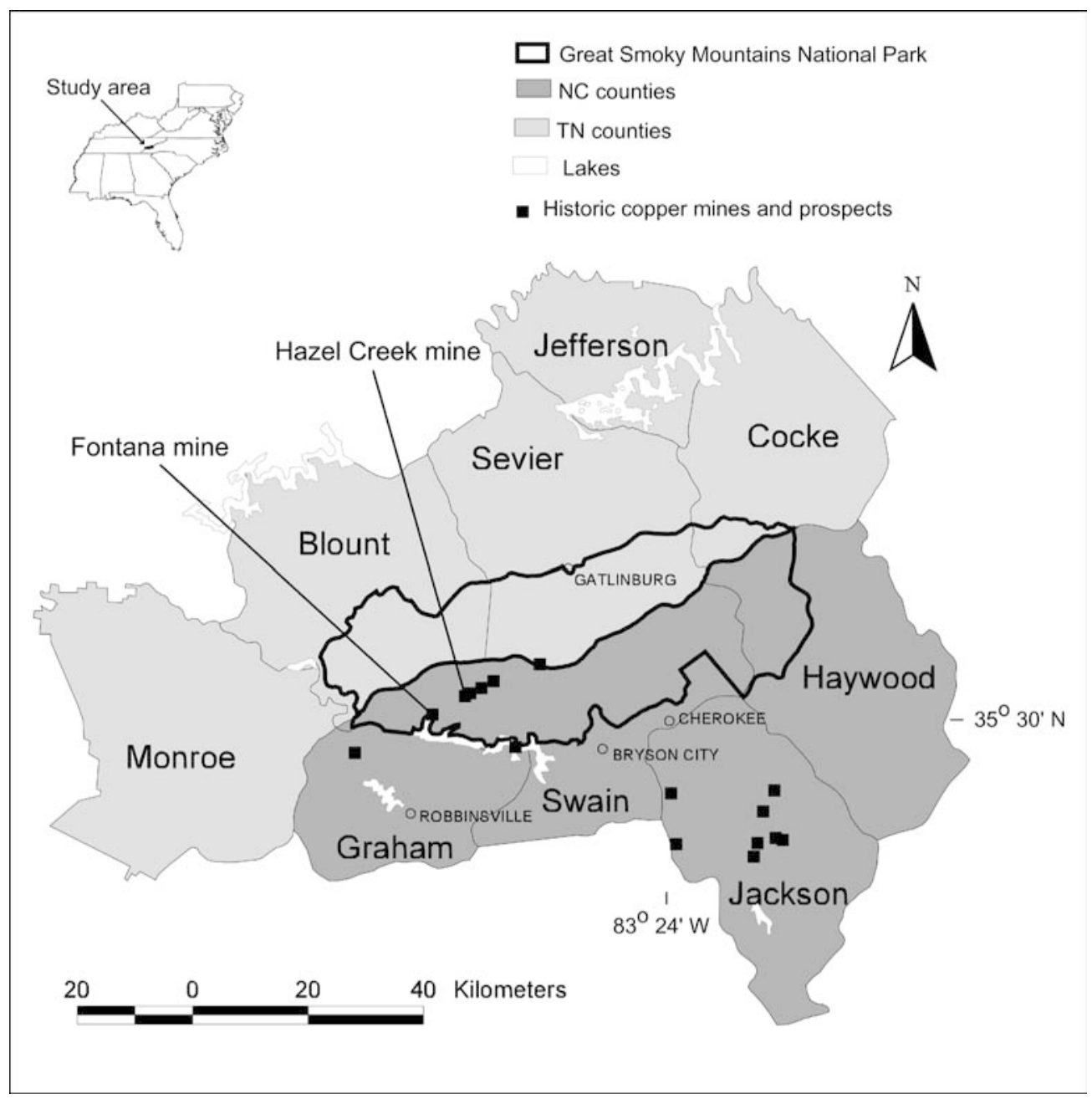

Fig. 1

Location map showing historic copper mines in the vicinity of Great Smoky Mountains National Park

This study investigates the role of varieties of solid materials in the cycling of metals, specifically in areas affected by natural and anthropogenic processes. Samples of a variety of different solid materials were collected from several different watersheds in the park to (1) document the geoenvironmental signature of copper mines in the climate of the southeastern USA, some 50 years after the mines were last active, (2) evaluate the role of secondary minerals in metal sequestration, and (3) compare stream sediments in mined areas with other areas in the park to provide baseline data and evaluate stream sediment geochemistry with respect to stream sediment quality guidelines. Mine waste, secondary mineral weathering products (precipitates, rock coatings, and efflorescent sulfate salts), and stream sediments were sampled in 1997 and 1998 as part of a study of factors that affect water quality associated with inactive copper mines in the park (Seal and others 1998). Sampling included a number of localities in popular areas of the park away from the mined areas, including several monitoring sites used by the National Park Service, and areas previously identified by Flum and Nodvin (1995) and Seal and others (1998) as having more acidic streams $(\mathrm{pH}<5)$ than streams draining mined areas $(\mathrm{pH}>5)$.

\section{Materials and methods}

\section{Study area}

Great Smoky Mountains National Park covers over $200,000 \mathrm{~km}^{2}$ in the Southern Appalachian Western Blue Ridge physiographic province in Tennessee and North Carolina (Fig. 1). Before the park was established in 1934, the area was farmed and extensively logged. Most of the park area is underlain by bedrock composed of Late Proterozoic metasedimentary rocks of the Great Smoky Group of the Ocoee Supergroup. King and others (1968) mapped the geology of the park at scales of 1:24,000, $1: 62,500$, and $1: 125,000$. For the purposes of this study, the lithogeochemical character of bedrock is emphasized, so a number of different stratigraphic units have been combined to illustrate the distribution of grossly similar rock types throughout the study area. The dominant lithologies in the Great Smoky Group include metasandstone, metaconglomerate, metasiltstone, and schist (Elkmont Sandstone, Thunderhead Sandstone) and carbonaceous schist, phyllite, and slate, collectively referred to as the Anakeesta Formation. Anakeesta Formation rocks crop out in narrow northeast-southwest-trending belts that cut across the central part of the park (Fig. 2). These rocks contain 


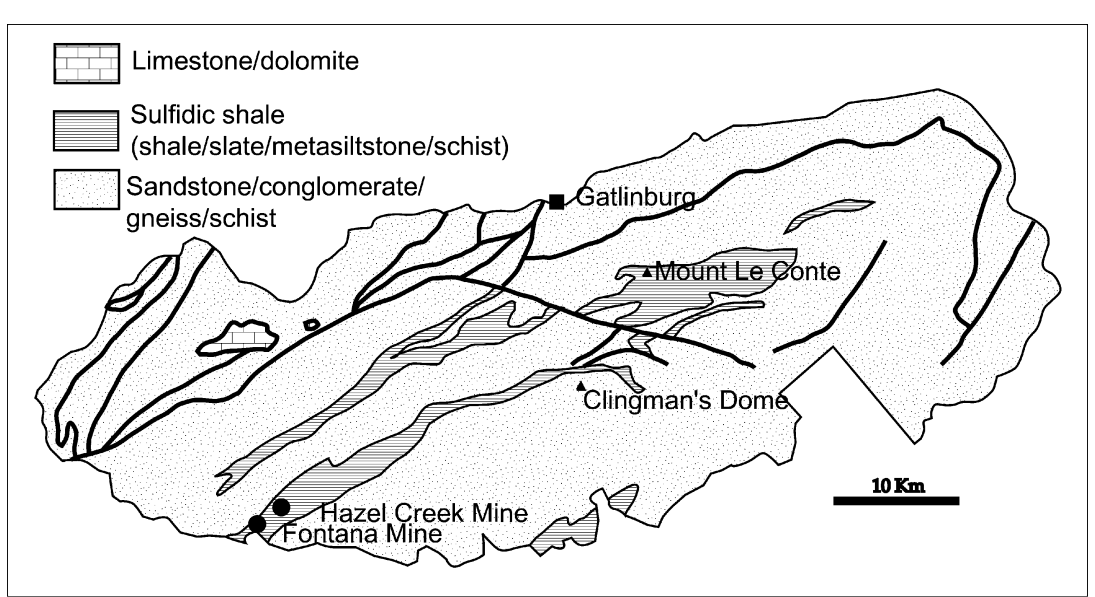

Fig. 2

Lithogeochemical map of Great Smoky Mountains National Park showing the distribution of various rock types. Heavy lines are faults. Modified from Southworth (1995) disseminated pyrite or pyrrhotite, host massive sulfide deposits, and form steep slopes that are subject to debris flows posing a threat to hikers (Schultz 1998). The metamorphic grade of the sulfidic rocks increases from northwest to southeast across the study area, such that the rocks vary from shale to slate to schist. In this paper, the general term "shale" was used to refer to all of the finegrained, sulfidic metasiltstones, shales, slates, and schists in the study area (Anakeesta Formation, Wehutty Formation). The sulfidic rocks also pose engineering problems throughout the region for construction of roads, powerlines, and stream diversion because of their high potential for acid generation (Byerly 1994, 1996; Tingle 1995; Schaeffer and Clawson 1996). Schultz (1998) documented the distribution of more than 25 Pleistocene to Recent debris flows within the Anakeesta Formation in the Mount LeConte area (Fig. 2). Sulfide minerals are reported throughout the rocks of the Great Smoky Group, but are most abundant in the slaty rocks of the Anakeesta Formation (King 1964; Huckabee and others 1975). Although minor amounts of dolomite are present in the Anakeesta Formation, major exposures of carbonate rocks in the park are confined to tectonic windows in the western part of the park in the Cades Cove area (Fig. 3). Hadley and Goldsmith (1963) analyzed rocks from the Anakeesta Formation from the central part of the park (muscovite-rich argillite near Alum Cave, quartz and feldspar-rich greywacke near Newfound Gap) for major elements, carbon, and total sulfur (up to $1.3 \%$ ), and observed sulfate minerals on weathered argillaceous greywacke along the highway north of Newfound Gap. Bacon and Maas (1979) documented Anakeesta Formation as a source of contaminants in two areas of the park. Beech Flats Creek is affected by weathering of rock exposed during a highway construction project. Anakeesta Formation is a natural source of acidity and metals in the Alum Cave Creek and Walker Prong areas. Seal and others (1999) sampled two high elevation springs along the Appalachian Trail that discharge from colluvium that overlies the contact between metasiltstone and metasandstone of the Anakeesta Formation and massive metaconglomerate of the underlying Thunderhead Sandstone. Their data showed that in terms of national secondary drinking water standards, ground- water in the area of the springs is acidic enough ( $\mathrm{pH}$ 5.3, 5.7) to rank below the recommended $\mathrm{pH}$ range (6.5 to 8.5) and aluminum concentrations are above recommended limits $(50 \mu \mathrm{g} / \mathrm{L})$. Although these data represent a single, dry period (late summer, 1998), they do indicate that the bedrock contributes acidity and that aluminum is mobile in the environment.

\section{Sample localities}

Localities sampled for this study include (1) areas impacted by historic copper mining in the southernmost part of the park, (2) areas where thick encrustations of secondary sulfate minerals are observed on outcrops of sulfidic rocks (Alum Cave, Road-to-Nowhere), (3) an area where Anakeesta rocks dumped from a new roadcut from highway construction in the 1960s weathered and impacted a stream in the immediate area (Beech Flats), (4) areas where modern debris flows have occurred in Anakeesta Formation rocks (Road Prong, Anakeesta Ridge, Alum Cave area), (5) streams that drain Anakeesta Formation, streams that drain areas of other lithologies in the park including metasandstone and carbonate (Chimneys, Cades Cove), and Fontana Lake (Fig. 3).

\section{Copper mines}

Seal and others (1998) showed that although underground mine waters are acidic and exceed acute toxicity limits for a number of heavy metals and aluminum in fresh water aquatic ecosystems, the small volumes of mine effluent are rapidly diluted. Furthermore, some of the streams in the park away from the mined areas, such as the Alum Cave area, exceeded toxicity limits for zinc and aluminum due to effects of natural weathering unperturbed by human activity.

Two copper mines, the Fontana mine and the Hazel Creek mine, operated intermittently as private in-holdings along the southern boundary of the park until 1944. Both deposits are hosted by graphitic and sulfidic metasiltstones (Southworth 1995). Host rocks for the mineral deposits, and lithologically similar rocks at the southeastern corner of the park, are not continuous with rocks at the type locality for the Anakeesta Formation at Anakeesta Ridge (Fig. 3). Different belts of these carbonaceous and sulfidic 


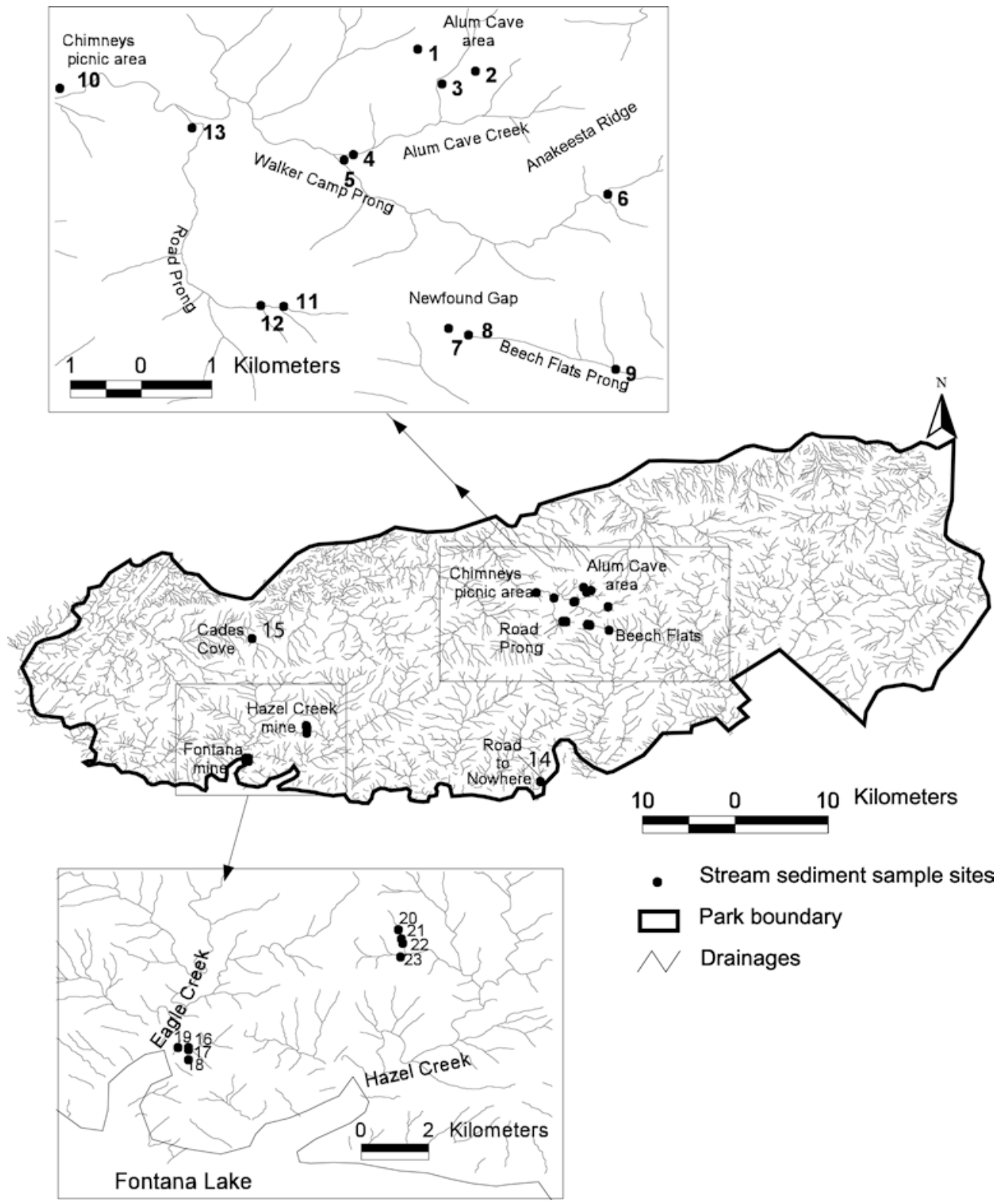

Fig. 3

Sample locations for stream sediments argillaceous metasedimentary rocks probably occupy different stratigraphic and structural positions (Southworth 1995). In contrast to the other major lithologies in the park however, all of these sulfidic rock units have a greater potential for negative environmental impacts caused by rock weathering.

The copper mines exploited pyrrhotite-rich, Besshi-type massive sulfide deposits (Robinson and others 1992) that lie along a northeast-trending belt of mines and prospects (Fig. 1) that include the world-class copper deposits at Copper Basin (Ducktown), Tennessee to the south. Both mines are situated along creeks (Fig. 3) that drain into Fontana Lake, a reservoir constructed in 1944 by damming the Little Tennessee River as part of the Tennessee Valley Authority's regional flood control and hydroelectric power program. The Fontana mine produced more than 500,000 metric tons of ore that averaged $7 \%$ copper, $2 \%$ zinc, $14 \mathrm{~g} / \mathrm{t}$ silver, and $0.28 \mathrm{~g} / \mathrm{t}$ gold
(Feiss and others 1991). All of the ore was shipped to smelters at Ducktown; no ore beneficiation was done on-site (Espenshade 1963). Underground workings at the Fontana mine extend beneath the present lake; minedump material and equipment were removed from the site at closure and the mine area is completely revegetated. An ephemeral feeder stream to Eagle Creek (Fig. 3 inset) flows past the mine adits and receives drainage from seeps; underground workings are largely flooded and surface discharge from the mine workings is minimal (Seal and others 1998). Due to periodic releases at Fontana Dam downstream, the lake level fluctuates dramatically over the course of a year. Hazel Creek mine, a much smaller mining operation (only 14 metric tons of ore produced), is situated along the Sugar Fork tributary of Hazel Creek (Fig. 3). Several mine dumps are present on the site; discharge from mine portals is volumetrically insignificant. 
In previous studies, stream sediment, rocks, soil, and ashed leaf litter from the copper mine areas were evaluated as part of a mineral resource assessment in the 1970s (Lesure and others 1977). Sediment in Fontana Lake was sampled for heavy metals in 1978 (Abernathy and others 1984). Walsh and Nimmo (1992) analyzed sediments and waters in a chemical and toxicological study focused on seepage from underground mine workings. Acute toxicity tests using a wetland plant (Ecinochloa crusgalli) and a crustacean (Ceriodaphnia dubia) showed that water from Sugar Fork was at most slightly toxic to plants and daphnids and that undiluted as well as diluted seep waters along Eagle Creek were highly toxic to C. dubia. Flohr and Hammarstrom (1997) studied the chemistry and mineralogy of gossan and partly oxidized ores from the mine dumps and showed that with progressive weathering of ore, pyrrhotite is replaced by marcasite and iron oxyhydroxides, and zinc is effectively removed from the system.

\section{Alum Cave}

Alum Cave is a bluff developed in rocks of the Anakeesta Formation, where water penetrating along fractures in the pyrite-rich shale facilitates oxidative weathering. Evaporation of sulfate-rich fluids during dry periods produces "blooms" of efflorescent sulfate salt minerals. Most of these minerals are highly soluble in water. However, the partly sheltered face of the bluff provides some protection from the weather and permits localized, centimeter-thick salts crusts to develop. Oxidation and hydrolysis of iron resulted in precipitation of iron-rich coatings and crusts. More than 20 secondary minerals have been described from this locality (Flohr and others 1995; Lauf 1997; Coskren and Lauf 2000) including new rareearth oxalate minerals (Cosken and Lauf 1996; Peacor and others 1999a; Rouse and others 2001) and a new occurrence of destinezite as a soil mineral (Peacor and others $1999 b)$. The salts were mined in the 1800s for "alum" hair salts, Epsom salt (epsomite), copperas (melanterite), and other minerals; the mineral alum is rare at the site (Coskren and Lauf 2000). No salt mining has occurred at the site since the Civil War. Drip water from a rock face along the Alum Cave trail sampled in June 1997 was acidic $(\mathrm{pH} 4)$ and contained more than $1,000 \mu \mathrm{g} / \mathrm{L}$ dissolved aluminum. The same site was dry in September 1998. In June 1997 and September 1998, a red-orange iron precipitate characteristic of acid drainage was observed in a stream in a debris flow scar that crosses the trail to Alum Cave; streamflow was reduced considerably at the time of the second visit. Sampling coincided with the highest (June 1997 ) and lowest (September 1998) average monthly precipitation during the 2-year period (Fig. 4). The drip water and the stream contained approximately $5 \mathrm{mg} / \mathrm{L}$ dissolved sulfate. Waters flowing from debris flow scars and chutes and various small drainages, such as Styx Branch, coalesce to form Alum Cave Creek, one of the headwater streams of the West Prong of the Little Pigeon River (Fig. 2).

Road-to-Nowhere

The Road-to-Nowhere is a similar salt occurrence along a road at the southeastern corner of the park where acid

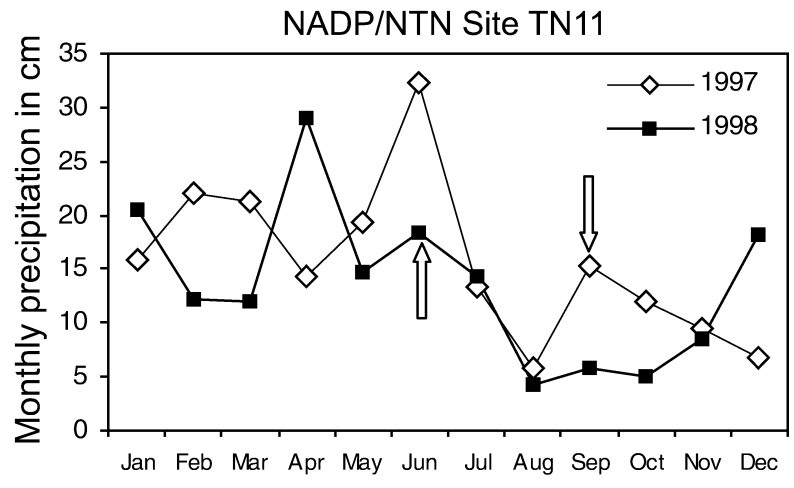

Fig. 4

Mean monthly precipitation in Great Smoky Mountains National Park for the study period, based on National Atmospheric Deposition Program data for site TN11 at Elkmont in Sevier County, TN. Arrows indicate sampling dates for this study

generation from pyrite weathering contributed to decisions to halt highway construction. Ochre forms on rock faces at acidic ( $\mathrm{pH} 4.1)$ groundwater seeps. Protected rock overhangs create settings that allow the highly soluble sulfate salts to develop and persist despite the high rates of precipitation in the Smokies.

Beech Flats

During relocation of Highway 441 near Newfound Gap, oxidation of pyritic rocks of the Anakeesta Formation that were excavated in 1963 and used for roadfill developed acidic ( $\mathrm{pH}$ 4.5) drainage in Beech Flats Prong (Fig. 2). White to yellowish aluminum hydroxide precipitates coated the streambed for a distance of $2 \mathrm{~km}$ downstream from the site, and killed native brook trout $8 \mathrm{~km}$ downstream from the site (Trumpf and others 1979). In September 1998, water in a culvert at the site that diverts the stream beneath the highway had a pH of 5.8, which dropped to 4.7 within $15 \mathrm{~m}$ as the stream flows over construction debris. White precipitate coating streambed rocks was sampled. Bacon and Maas (1979) reported on metal contents of bottom sediments from Beech Flats Creek, Alum Cave Creek, and Walker Prong and identified the roadfill material as a point source of acidity and metals, especially manganese and zinc.

\section{Debris flows}

Debris flows are deposits of boulders, cobbles, and pebbles of metasandstone, metasiltstone, and shale in a matrix of soil, clay and vegetation that includes trees, grass, and brush (Schultz 1998). In the Mount Le Conte quadrangle, which covers the Alum Cave and Anakeesta Ridge areas, Schultz (1998) separately mapped pre-1970, post-1900, and post-1970 debris flow tracks and deposits; mapped debris flow thicknesses range from 2 to $10 \mathrm{~m}$. On steep slopes at high elevations, ochre stains and crusts and efflorescent sulfate salts form on Anakeesta Formation rock surfaces exposed in wedge failures that formed debris flows. Where streams flow through debris flow deposits, the streambed may be coated with red-orange ochre precipitates that mimic acid-mine drainage. Waters and solids were 
sampled at two post-1970 debris flows in the Mount Le Conte area (Huggins Hell slide along Styx Branch below Alum Cave and Anakeesta Ridge) and at a 1996 debris flow that impacted Road Prong (Fig. 3).

\section{Streams}

Stream sediments and waters were sampled from streams draining copper mine areas and adjacent drainages. In addition, streams were sampled in catchment areas draining carbonate rocks at Cades Cove, metasiltstone at the Chimneys picnic area, and shales near Alum Cave, along Road Prong, and Peachtree Creek along the Roadto-Nowhere (Fig. 3). A number of sample sites (NPS sites, Table 6) were co-located with National Park Service monitoring sites in the central part of the park along Alum Cave Creek, Walker Camp Prong, Road Prong, and West Fork Little Pigeon River.

\section{Sample media and sampling methods}

Mine waste

No recognizable mine dump material remains on-site at the Fontana mine. At the Hazel Creek mine, a small mine dump $\left(<500 \mathrm{~m}^{3}\right)$ composed of oxidized soil, gossan, and waste rock from the mining operation is a few meters above a tributary of the Sugar Fork of Hazel Creek. The upper part of the dump (proximal to collapsed mine shafts) and the lower dump (closest to the creek) were sampled separately. Composites of the upper and lower mine dump surface soils ( $<2 \mathrm{~mm}$ fraction) were collected by taking 30 -increment auger samples in a random grid pattern across the dump surface. This sampling protocol was developed by Smith and others (2000) as a statistically based, cost-effective sampling strategy for screening and prioritizing mine waste piles for remediation on a regional or a watershed scale. Use of the $<2 \mathrm{~mm}$ fraction reduces sampling error and sample size, and provides an estimate of the worst-case scenario for metal leachability. For the upper dump, the topmost $2.5 \mathrm{~cm}$ and the $10-11 \mathrm{~cm}$ depth intervals were sampled separately. The topmost $2.5 \mathrm{~cm}$ interval was sampled for the lower dump. Samples were removed from the auger, dry-sieved through a 10 mesh $(2 \mathrm{~mm})$ stainless steel sieve set over a plastic gold pan, and packed in plastic bags for transport. Paste $\mathrm{pH}$ was measured on $<2 \mathrm{~mm}$ material in the field. Samples were air-dried, split, and pulverized for multi-element geochemical analysis and mineralogical characterization by X-ray diffraction.

Lower dump surface material was submitted to Activation Laboratories, Ltd, Ontario, Canada, for acid-base accounting by a modified Sobek method (Lawrence and Wang 1997); the sample was also subjected to a passive leach test (Hageman and Briggs 2000) to simulate leaching that might occur during rainstorms.

Although Alum Cave is not a copper mine, the soil below the bluff includes mine waste from historic salt mining as well as soil developed from natural weathering of the outcrop. Heavy foot traffic through the area contributes to erosion of the fissile shale. A composite (30 increment) soil $(<2 \mathrm{~mm})$ sample was collected from a clearing at the base of the bluff and along the hiking trail to provide information on soil chemistry at the site in response to concerns about potential adverse health effects to hikers.

\section{Secondary minerals and precipitates}

Secondary minerals form from alteration of primary minerals by weathering. Processes that can lead to precipitation of secondary minerals include evaporation, oxidation, reduction, dilution, mixing, and neutralization (Alpers and others 1994). Secondary weathering products sampled for this study include precipitates that form ochre deposits in streambeds and at groundwater seeps, coatings on rocks in and along streambeds, and efflorescent salts that coat rock outcrops.

Ochre deposits include flocs, muds, and hardpan crusts. Samples were collected with a syringe, by scraping coated rocks, or by cutting out crusts with a knife. Ochre samples were air-dried, split, and pulverized for multi-element geochemical analysis. Mineralogy was characterized by $\mathrm{X}$-ray diffraction and scanning electron microscopy. Hammarstrom and others (2000) described aspects of the mineralogy and chemistry of efflorescent sulfate salts from Alum Cave and from the Road-to-Nowhere localities, as well as sampling and analytical methods for the study of these minerals. Additional data specific to each sample site are reported here.

\section{Stream sediments}

Stream sediments were sampled at 30 localities throughout the park (Fig. 3) that coincide with surface water sampling sites (Seal and others 1998). Samples were collected along stream segments (typically $30 \mathrm{~m}$ or less) by sampling 30 increments of the uppermost $5 \mathrm{~cm}$ of sediment with a stainless steel trowel; wherever possible, the entire stream width was included. Stream sediment samples comprised at least 30 subsamples (increments) to minimize sampling errors (Pitard 1993). The Fontana Lake shoreline fluctuates as the lake level is adjusted by release of water at the dam downstream from the mine sites. Sediments were sampled at the edge of the lake at the confluence of the small stream that drains the Fontana mine area in 1997 and again in 1998 when the water level was lower. In 1998, a trowel was used to collect 30 increments of the upper $1 \mathrm{~cm}$ of exposed lake bottom sediment and an auger was used to collect 30 increments of the sediment at a depth of $20 \mathrm{~cm}$ to investigate changes in sediment column composition. Replicate samples were collected at localities 1, 6, and 13 (Fig. 3).

Sediments were wet-sieved in the field through a 10 mesh $(2 \mathrm{~mm})$ stainless steel sieve; a minimum of $1 \mathrm{~kg}$ of $<2 \mathrm{~mm}$ sediment was transported back to the laboratory in plastic bags. Sediments were air-dried, the $<80$ mesh $(<0.177 \mathrm{~mm})$ fraction was sieved out, subsampled, pulverized, and approximately $85 \mathrm{~g}$ of $<150$ mesh material was submitted for chemical analysis. Mineralogy was characterized by $\mathrm{X}$-ray diffraction on pressed powder mounts.

\section{Waters}

Water data cited in this report are from Seal and others (1998), with additional samples for Beech Flats Creek, 
Road Prong, and the Anakeesta Ridge area that were collected in 1998 and analyzed by the same methods. Water data relevant to this discussion are summarized in the online supplementary material (Tables ESM 1 and ESM 4).

\section{Analytical techniques}

Geochemical methods

Mine waste, ochres, and stream sediments were analyzed by inductively coupled plasma-atomic emission spectroscopy (ICP-AES) following a multi-acid sample digestion at low temperatures (Crock and others 1983) using calibration procedures of Lichte and others (1987). Gold was analyzed by graphite furnace atomic absorption spectrophotometry (method GFAA) following the procedure of Meier (1980); arsenic was analyzed by atomic absorption following a gas hydride generation step (method AAH3). A cold vapor method (O'Leary and others 1996) was used in combination with an automated analyzer for mercury (method CVAC). For selected samples, carbon and sulfur were determined by automated LECO $^{1}$ furnace analyzers with infrared detectors. Analyses were performed by XRAL Laboratories, Inc. Details of analytical procedure, analytical performance criteria, and detection limits for these methods are discussed in Van Gosen and others (2000). Detection limits for ICP-AES are in the parts per million range.

Selected ochre samples and precipitates, Alum Cave soil, and leachates were analyzed in USGS laboratories by inductively coupled plasma mass spectrometry (ICP-MS) using a multi-element method developed by Meier and others (1994) with detection limits in the parts per billion range. Selected samples (10-20 mg range) of air-dried precipitates were analyzed for thermogravimetry in a Mettler TGA/SDTA851e thermal analyzer coupled to a Balzers quadrupole mass spectrometer for qualitative evolved gas analysis. Samples were heated from 22 to $1,000{ }^{\circ} \mathrm{C}$ in flowing argon at a rate of $10{ }^{\circ} \mathrm{C} / \mathrm{min}$. Appropriate mass numbers for $\mathrm{H}_{2} \mathrm{O}, \mathrm{CO}_{2}, \mathrm{SO}_{2}, \mathrm{O}_{2}$, and $\mathrm{N}_{2}$ as probable parent molecules for any evolved gas species were monitored during the runs.

\section{Mineralogical methods}

Minerals were identified by powder X-ray diffraction (XRD) using a Scintag X1 automated powder diffractometer equipped with a Peltier detector with $\mathrm{CuK} \alpha$ radiation. Samples were prepared as side-loading dry powder mounts, pressed pellets, or smear mounts on zerobackground quartz plates with alcohol as a binder. Salts were sorted under a binocular microscope, hand picked, and lightly ground in agate or, in cases where the minerals were extremely hygroscopic, smeared onto quartz plates for XRD. Hand-picked salts were also examined using a JEOL JSM-840 scanning electron microscope (SEM) equipped with a back-scattered electron (BSE) detector, a secondary electron (SE) detector, and a PGT X-ray energy

\footnotetext{
${ }^{1}$ All trade and firm names are for descriptive purposes only and do not imply endorsement by the USGS.
}

dispersive system (EDS). A semiquantitative, standardless software package was used to estimate atomic proportions of elements in salts to verify and refine XRD identifications. The SEM typically was operated at an accelerating voltage of $15 \mathrm{kV}$ and a specimen current of 1 to $2 \mathrm{nA}$.

\section{Results}

\section{Mine waste}

The Hazel Creek mine waste dump (Table 1) contains elevated concentrations of base metals $(>7,000 \mathrm{mg} / \mathrm{kg}$ copper+lead+zinc). Copper is the most abundant base metal; lead and zinc are subequal. The highest concentrations for all base metals, iron, and manganese are observed for the near-surface (upper $2 \mathrm{~cm}$ ) composite from the upper part of the dump; lower concentrations of all these metals were found in the lower part of the dump. Metal concentrations at depth $(8 \mathrm{~cm})$ in the upper dump are comparable to those in the surface sample. Arsenic concentrations are below detection limits $(<10 \mathrm{mg} / \mathrm{kg})$. Field paste-pH measurements, an indication of readily available alkalinity (paste $\mathrm{pH}>7$ ) or acidity (paste $\mathrm{pH}<5$ ), reveal a lack of alkalinity in the mine waste. Acid-base accounting on the lower mine dump sample includes a laboratory paste-pH measurement (4.06) in good agreement with our field measurement (3.9). One third of the total sulfur $(0.66 \mathrm{wt} \%)$ in the mine dump sample is present as sulfate sulfur; the material has no neutralization potential (i.e., negative NP), has measurable acid-producing potential $\left(13.8 \mathrm{~kg} \mathrm{CaCO}_{3} / \mathrm{t}\right)$, and a net neutralization potential (NNP) of $-61 \mathrm{~kg} \mathrm{CaCO}_{3} / \mathrm{t}$. Soil at the base of Alum Cave (Table 1) is sulfur-rich (1.64\% total S) and acidic in terms of paste $\mathrm{pH}$ (4.8). With the exception of sulfur, all of the elements analyzed fall within element concentration ranges observed for eastern US soils as reported by Shacklette and Boerngen (1984). The Alum Cave soil arsenic concentration $(52 \mathrm{mg} / \mathrm{kg})$ is well above the mean eastern soil concentration of $4.8 \mathrm{mg} / \mathrm{kg}$, and more than twice the preliminary remediation goal for residential soil of $22 \mathrm{mg} / \mathrm{kg}$ set by the EPA. However, the Alum Cave soil arsenic concentration is within the observed range for soils $(<0.1$ to $73 \mathrm{mg} / \mathrm{kg}$ ) and well below the EPA goal for industrial soils of $440 \mathrm{mg} / \mathrm{kg}$ (US EPA 2000).

\section{Secondary minerals}

\section{Ochres}

Poorly crystalline, insoluble streambed precipitates of iron are hallmarks of sulfide oxidation and associated acidic drainage (Bigham and Nordstrom 2000). Typical ochre minerals formed by weathering of iron sulfide minerals include the ferric iron oxyhydroxide minerals ferrihydrite, goethite, and lepidocrocite and the iron hydroxysulfate minerals schwertmannite and jarosite. The particular minerals that form reflect local $\mathrm{pH}$ and dissolved sulfate concentrations. In addition, these minerals can be important in self-mitigation of metal-laden acidic streams because of 
Table 1

Chemistry of composite surface materials $(<2 \mathrm{~mm})$. Sample locations and depths follow the sample names. N.A. Not analyzed

\begin{tabular}{|c|c|c|c|c|c|}
\hline \multirow[t]{2}{*}{ Element } & \multicolumn{3}{|c|}{ Hazel Creek mine dump ${ }^{a}$} & \multirow{2}{*}{$\begin{array}{l}\text { Alum Cave bluff } \\
\text { 98AC-soil } \\
\text { Soil below bluff } \\
2 \mathrm{~cm}\end{array}$} & \multirow[t]{2}{*}{ Eastern US soils ${ }^{\mathrm{c}}$} \\
\hline & $\begin{array}{l}\text { HCM-DUMP1A } \\
\text { Upper dump } \\
2 \mathrm{~cm}\end{array}$ & $\begin{array}{l}\text { HCM-DUMP1B } \\
\text { Upper dump } \\
8 \mathrm{~cm}\end{array}$ & $\begin{array}{l}\text { HCM-DUMP2A } \\
\text { Lower dump } \\
2 \mathrm{~cm}\end{array}$ & & \\
\hline \multicolumn{6}{|c|}{ Major elements (\%) } \\
\hline $\mathrm{Al}$ & 8.3 & 8.8 & 8.3 & 11 & $0.7->10$ \\
\hline $\mathrm{Ca}$ & 0.12 & 0.12 & 0.23 & 1.7 & $0.01-28$ \\
\hline $\mathrm{Fe}$ & 10 & 9.4 & 8.8 & 6.6 & $0.01->10$ \\
\hline $\mathrm{K}$ & 1.7 & 2 & 2.6 & 2.2 & $0.005-3.7$ \\
\hline $\mathrm{Mg}$ & 3.9 & 3.7 & 2.9 & 0.9 & $0.005-5$ \\
\hline $\mathrm{Na}$ & 0.26 & 0.3 & 0.48 & 1.3 & $<0.005-5$ \\
\hline $\mathrm{P}$ & 0.07 & 0.08 & 0.08 & N.A. & N.A \\
\hline $\mathrm{Ti}$ & 0.29 & 0.32 & 0.29 & N.A & N.A \\
\hline Total S & N.A. & N.A. & 0.66 & 1.64 & $0.08-0.31$ \\
\hline Total C & N.A. & N.A. & N.A. & 0.9 & $0.06-37$ \\
\hline \multicolumn{6}{|c|}{ Minor and trace elements $(\mathrm{mg} / \mathrm{kg})$} \\
\hline $\mathrm{Ag}$ & 12 & 8 & 4 & 0.27 & N.A. \\
\hline As & $<10$ & $<10$ & $<10$ & 52 & $<0.1-73$ \\
\hline $\mathrm{Ba}$ & 460 & 553 & 686 & 500 & $10-1,500$ \\
\hline $\mathrm{Be}$ & 2 & 2 & 2 & 3.6 & $<1-7$ \\
\hline $\mathrm{Bi}$ & 34 & 30 & 17 & N.A. & N.A. \\
\hline $\mathrm{Cd}$ & $<2$ & $<2$ & $<2$ & $<0.1$ & $<0.5-5.3$ \\
\hline $\mathrm{Ce}$ & 124 & 130 & 65 & N.A. & $<150-300$ \\
\hline Co & 24 & 21 & 6 & 19 & $<0.3-70$ \\
\hline $\mathrm{Cr}$ & 54 & 52 & 35 & 45 & $1-1,000$ \\
\hline $\mathrm{Cu}$ & 10,200 & 8,350 & 4,430 & 40 & $<1-700$ \\
\hline $\mathrm{Eu}$ & 4 & 4 & 2 & N.A. & N.A. \\
\hline $\mathrm{Ga}$ & 32 & 25 & 23 & N.A. & $<5-70$ \\
\hline $\mathrm{La}$ & 84 & 90 & 40 & N.A. & $<30-200$ \\
\hline $\mathrm{Li}$ & 38 & 39 & 36 & N.A. & $<5-140$ \\
\hline $\mathrm{Mn}$ & 1,210 & 1,150 & 747 & 2,200 & $<2-7,000$ \\
\hline $\mathrm{Nb}$ & 14 & 15 & 13 & N.A. & $<10-50$ \\
\hline $\mathrm{Nd}$ & 83 & 87 & 33 & N.A. & $<70-300$ \\
\hline $\mathrm{Ni}$ & 18 & 19 & 9 & 18 & $<5-700$ \\
\hline $\mathrm{Pb}$ & 1,590 & 1,380 & 1,570 & 29 & $<10-300$ \\
\hline $\mathrm{Sb}$ & N.A. & N.A. & N.A. & 0.9 & $<1-8.8$ \\
\hline Sc & 15 & 16 & 14 & N.A. & $<5-30$ \\
\hline $\mathrm{Sn}$ & 53 & 42 & 22 & N.A. & $<0.1-10$ \\
\hline $\mathrm{Sr}$ & 35 & 39 & 59 & N.A. & $<5-700$ \\
\hline Th & 19 & 19 & 16 & N.A. & $2.2-23$ \\
\hline $\mathrm{V}$ & 117 & 113 & 110 & 57 & $<7-300$ \\
\hline $\mathrm{Y}$ & 51 & 50 & 16 & N.A. & $<10-200$ \\
\hline $\mathrm{Yb}$ & 5 & 5 & 2 & N.A. & $<1-50$ \\
\hline $\mathrm{Zn}$ & 1,180 & 1,310 & 2,420 & 96 & $<5-2,500$ \\
\hline Field paste $\mathrm{pH}$ & 5.6 & 5.5 & 3.9 & 4.8 & - \\
\hline
\end{tabular}

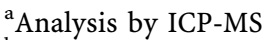

${ }^{\mathrm{b}}$ Analysis by ICP-AES

${ }^{c}$ Range of element concentrations in eastern US soils from Shacklette and Boerngen (1984, Table 2)

their high surface areas and ability to sorb dissolved contaminants. Schwertmannite, $\mathrm{Fe}_{8} \mathrm{O}_{8}(\mathrm{OH})_{6} \mathrm{SO}_{4} \cdot \mathrm{nH}_{2} \mathrm{O}$, is a poorly crystalline yellow mineral that typically forms in acid-sulfate waters in the $\mathrm{pH}$ range from 2 to 4 (Bigham and Nordstrom 2000) mixed with other poorly crystalline and metastable iron minerals. Jarosite is straw yellow, precipitates at lower $\mathrm{pH}$ in the presence of higher concentrations of dissolved sulfate, and forms euhedral pseudocubic crystals. Ferrihydrite is reddish-brown, very poorly crystalline, lacks sulfur in its structure (approximately $5 \mathrm{Fe}_{2} \mathrm{O}_{3} \cdot 9 \mathrm{H}_{2} \mathrm{O}$ ), and precipitates from more neutral waters. All of these minerals are considered metastable with respect to yellowish-brown goethite.

Ochres ranging from streambed precipitates to hardpan crusts were sampled where present at stream sediment and water sample localities throughout the park. Stalactites forming on mine adit ceilings were also collected. Geochemical data for ochres are listed in Table 2. Sample descriptions as well as $\mathrm{pH}$ and conductivity data for associated waters are available as online supplementary material (Table ESM 1). Figure 5 compares the range in mineralogy and degree of crystallinity of these samples with end member ochre minerals. Well-crystallized goethite is present, along with minor quartz, in a rustycolored crust (ANRS-3) that formed from oxidation of pyritic rocks exposed in the debris flow scar on Anakeesta Ridge (Fig. 6). In ponded surface water runoff in the channel at the base of the slide, a coating of amorphous white slime precipitate (Table 2, no. 3, sample ANRS4-A) overlies a thicker accumulation of poorly crystalline red 
Table 2

Ochres. Analyses by ICP-MS or ICP-AES and other methods. See text for explanation and references. n.d. no data

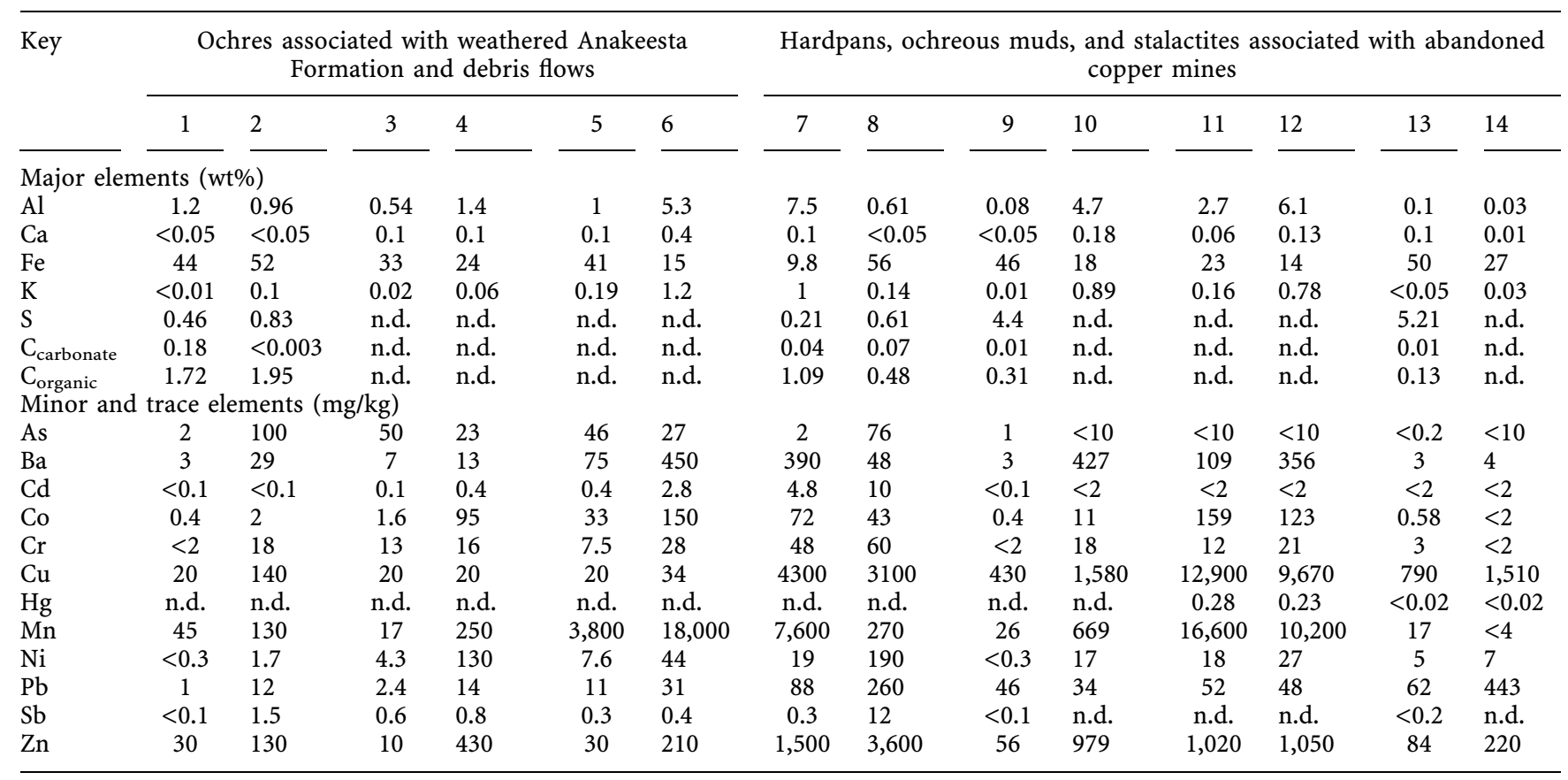
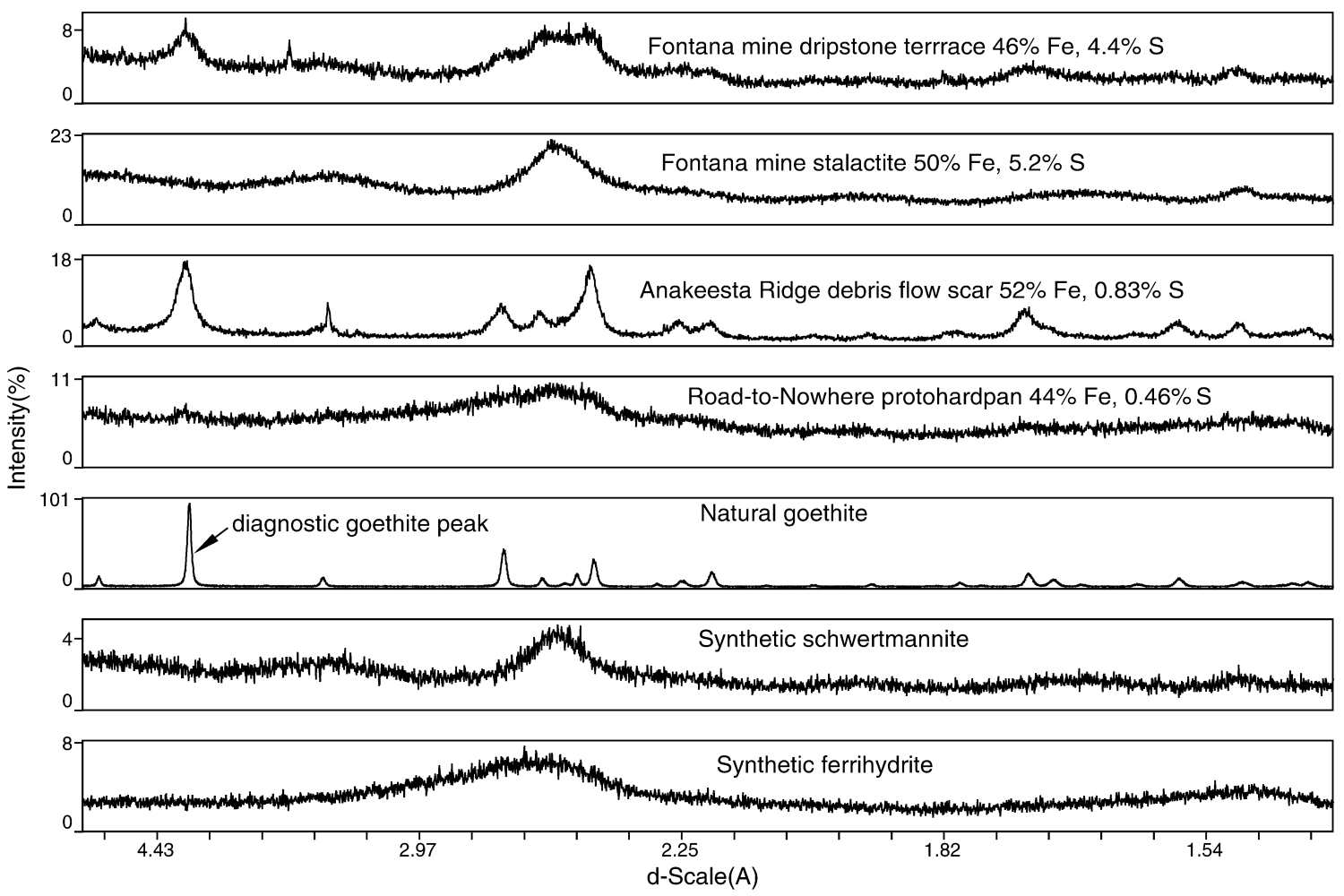

Fig. 5

X-ray diffraction patterns for ochres. Synthetic ferrihydrite and schwertmannite patterns and nominal goethite peaks (stick diagram) are shown for reference. See Table 2 for sample descriptions and complete chemistry

slime (Table 2, no. 4, sample ANRS4-B) that produces an XRD pattern compatible with schwertmannite. Red floc that mimics acid-mine drainage minerals in $\mathrm{pH} 4.6$ waters along Alum Cave Creek trail below Alum Cave is ferrihydrite; autotrophic (Galionella) and heterotrophic (Siderocapsa, Leptothrix ochracea) bacteria compatible with a neutral rather than an acidic environment were identified in a wet sample of the red floc (E. Robbins, USGS, personal communication, 2000). Iron-rich crusts, dripstone terraces, and stalactites lining the adits at the Fontana and Hazel Creek mines range from schwertmannite to 


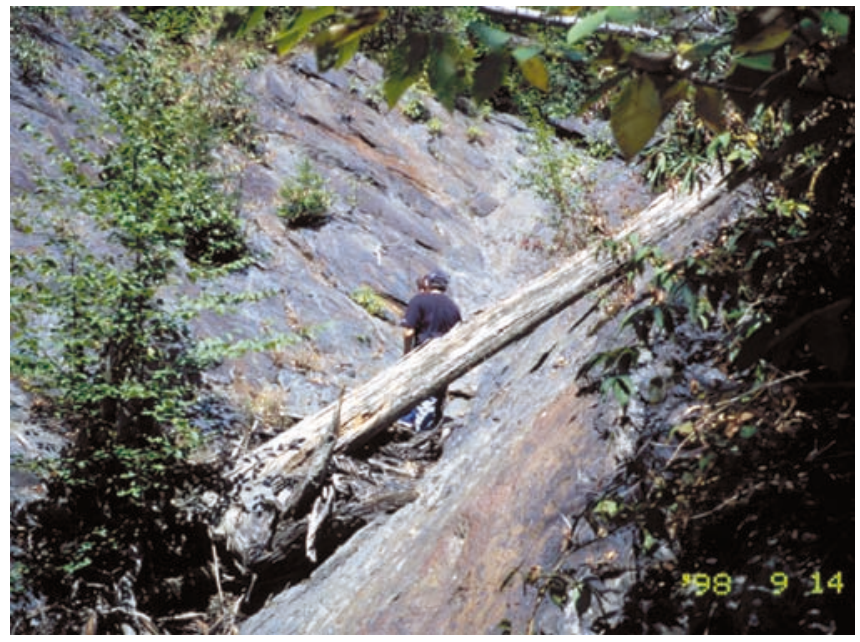

Fig. 6

Photo of the 1986 debris flow scar on Anakeesta Ridge. Oxidation of disseminated pyrite in the black shale (Anakeesta Formation) forms a goethite-rich red crust. Locally, white salts (rozenite) coat the surface. Water ponded at the base of the debris flow measured $\mathrm{pH} 4$ and contained white and red precipitates when the site was visited in September 1998. Within a few meters downstream, $\mathrm{pH}$ increased to 6

moderately well-crystallized goethite. Jarosite is present as a yellow mineral lining the inside of a goethite-rich stalactite at the Hazel Creek mine. Drip water from the stalactite had a $\mathrm{pH}$ of 6.4 , compatible with precipitation of goethite or ferrihydrite that may have aged to form goethite. The jarosite lining the inner parts of the stalactite probably records an earlier growth stage from more acidic waters. A stalactite and dripstone formation at the Fontana mine (Table 2, nos. 9 and 13) are associated with $\mathrm{pH} 3$ waters. The stalactite is composed of schwertmannite and the dripstone is a mixture of schwertmannite and goethite (Fig. 5). The sulfur content ( $\left.13 \mathrm{wt} \% \mathrm{SO}_{3}\right)$ of the schwertmannite stalactite is comparable to compositions for synthetic and natural schwertmannites (7.4 to $14.7 \mathrm{wt} \%$ $\mathrm{SO}_{3}$ ) reported by Bigham and Nordstrom (2000). TGA-EGA analysis of a $10 \mathrm{mg}$ sample of the same material used for chemical analysis showed a mass loss of $21.1 \%$ water over the temperature range from 22 to $400{ }^{\circ} \mathrm{C}$, followed by a loss of an additional $13.1 \%$ due to $\mathrm{SO}_{2}$ release at about $600{ }^{\circ} \mathrm{C}$ (in an argon atmosphere). The iron content $(50 \% \mathrm{Fe})$, when converted to $\mathrm{Fe}_{2} \mathrm{O}_{3}$, yields an iron concentration that appears to be too high $\left(71 \% \mathrm{Fe}_{2} \mathrm{O}_{3}\right)$ for pure schwertmannite (58-67\% $\mathrm{Fe}_{2} \mathrm{O}_{3}$ range). This is interpreted to be too high based on the difference between $100 \%$ and the observed weight losses due to water and sulfate, and may indicate an analytical problem or an additional iron phase. The precipitate at an acidic $(\mathrm{pH} 4)$ groundwater seep along the Road-to-Nowhere (Fig. 5 and Table 2, no. 1) is ironrich, poorly crystalline, and metal-poor $(<100 \mathrm{mg} / \mathrm{kg}$ base metals). In contrast, a near-neutral ( $\mathrm{pH}$ 6.2) oxidized (dissolved oxygen $11.0 \mathrm{mg} / \mathrm{L}$ ) groundwater seep immediately below the Fontana mine workings precipitates an ochre mud in a small seep pool (Table 2, no. 11, sample FM-9-2A) that forms an iron bog adjacent to the creek that drains the mine workings. The bog below the seep pool contains a thick $(45 \mathrm{~cm})$ accumulation of ochre mud
(Table 2, no. 12, sample FM-9-2C). Ochres in the bog are red-brown in color suggesting that they are iron-rich; chemical analysis shows that they actually contain less iron than some of the other samples, but are enriched in base metals $(\mathrm{Cu}>\mathrm{Zn}>\mathrm{Pb})$ and manganese (Table 2). Detrital silicate mineral grains (quartz, chlorite, and micas) identified by XRD are a significant component of the bog ochres. No sulfide minerals were detected by XRD. Most of the carbon in the ochres is present as organic carbon. Secondary electron images of ochres reveal textures such as microspheres and rods that suggest bacterial origin (Fig. 7); EDS spectra show that minor to trace amounts of sulfur are ubiquitous in the ochres at the micrometer scale, along with silicon, aluminum, and in some cases phosphorous and carbon well in excess of the carbon that can be attributed to sample coating. The presence of organic carbon and sulfur in the chemical analysis of the bulk sample could reflect plant fragments and detrital sulfide mineral grains, respectively. SEM detection of these elements in multiple particles at the micrometer scale suggests that these elements are contained in the secondary mineral phase. The elements $\mathrm{C}, \mathrm{H}, \mathrm{O}, \mathrm{N}, \mathrm{P}$, and $\mathrm{S}$ are the necessary ingredients of organic molecules. Documentation of these elements in ochres (water and nitrogen are confirmed by evolved gas-thermogravimetric analysis in an argon atmosphere) provides further indication of the intimate association between bacteria and ochre minerals in natural systems. Bigham and Nordstrom (2000) discussed the importance of bacteria in pyrite oxidation, but noted that this role does not necessarily imply that the ochre minerals are biological precipitates. They presented evidence for non-biological origins of poorly crystalline iron and aluminum hydroxysulfate and oxyhydroxide minerals in acidsulfate waters, and noted that $\mathrm{pH}$ is the master variable controlling secondary mineral speciation in acid-sulfate waters.

White precipitate coating the streambed at Beech Flats immediately downstream of the 1963 road construction site consists of XRD-amorphous, aluminum-rich, micrometer-scale (or smaller) particles containing minor Si and S (Fig. 8a) that form on lichen-coated streambed rocks. The 1998 stream $\mathrm{pH}$ measurements made for the present study range from 4.6 to 5.8 in this area; $\mathrm{pH}$ was 6.2 immediately upstream and several kilometres downstream of the site. For July 1975 to July 1976 monitoring of the site, Bacon and Maas (1979) reported mean weekly pH of 6.7 for the upstream site, 4.6 for the impacted area, and 5.8 for the far downstream site with mean weekly fluctuations of $0.2 \mathrm{pH}$ units. Hermann and others (1979) described similar depressions in stream $\mathrm{pH}$ below the fill, concomitant with increases in dissolved aluminum (0.01 to $6.9 \mathrm{mg} / \mathrm{kg}$ ) and sulfate ( 0.59 to $132 \mathrm{mg} / \mathrm{kg}$ ) concentrations in stream waters, and identified the precipitant as mainly aluminum hydroxide. Filtered $(0.45 \mu \mathrm{m})$ and unfiltered stream waters sampled in 1998 (Table 3) indicate that some 25 years later, the roadfill material continues to contribute aluminum to the stream. Raw waters consistently contain higher concentrations of aluminum (as well as iron and manganese) than filtered $(0.45 \mu \mathrm{m})$ waters; thus, fine particulates or colloids are important 

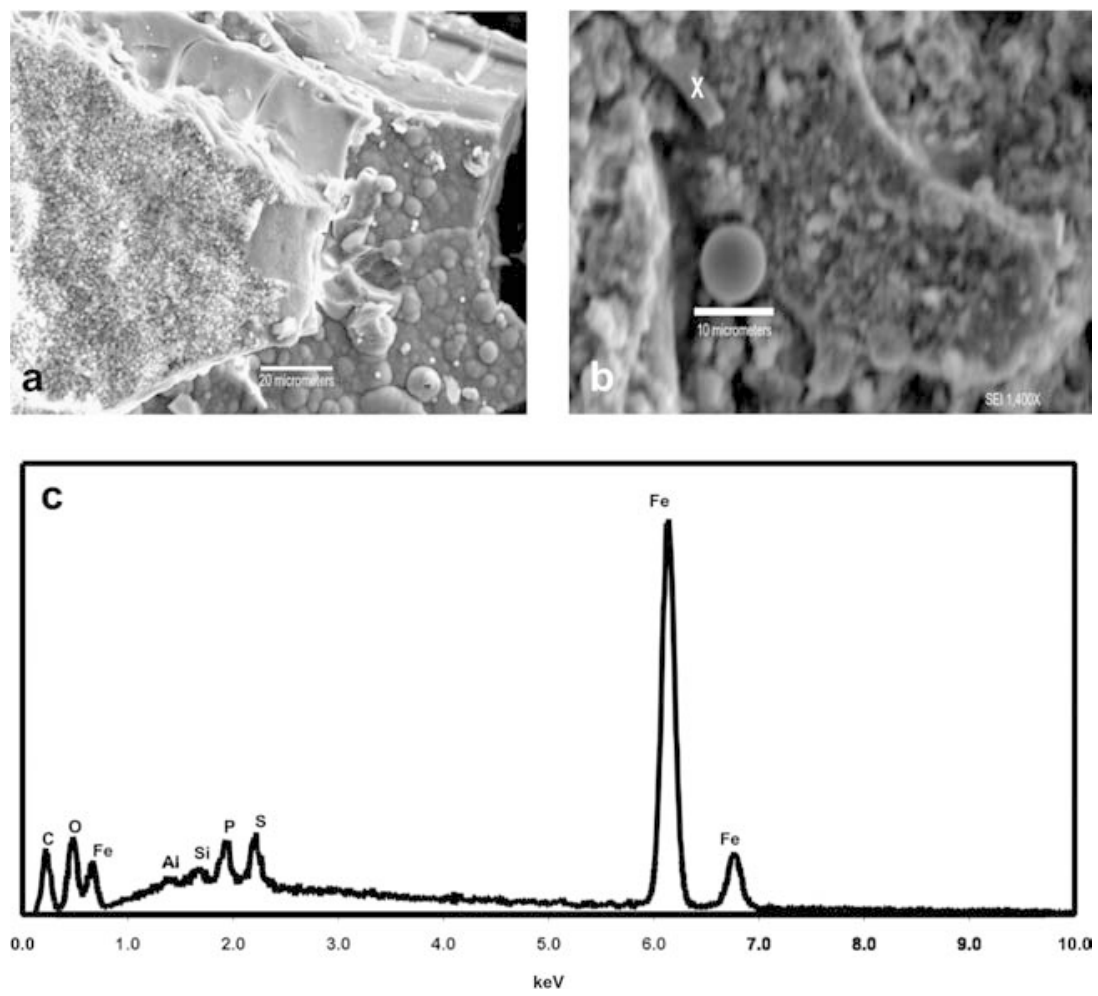

Fig. 7

SEM data for ochres.a Secondary-electron image of schwertmannite-rich Fontana mine stalactite (FM-2B-96) showing smooth layers alternating with microspheres suggestive of bacterial origin. b Secondary-electron image of goethite-rich gossan crust (ANRS-3) coating the Anakeesta Ridge debris flow scar. Microsphere above the scale is silica-rich. $c$ EDS spectrum for point " $x$ " in b shows that, in addition to iron and traces of silicon and aluminum, elements characteristic of organic matter $(\mathrm{C}, \mathrm{O}, \mathrm{P}, \mathrm{S})$ are preserved controls on these elements in the stream. For example, the unfiltered water split at sample site BCFT4-3 contains $4,500 \mu \mathrm{g} / \mathrm{L} \mathrm{Al}$, whereas the filtered split contained $220 \mu \mathrm{g} / \mathrm{L} \mathrm{Al}$.

EDS spectra obtained on different areas on several different mounts of white precipitate collected in 1998 consistently show peaks for silicon and sulfur (Fig. 8a). XRD patterns show a single sharp peak for the strongest line of quartz. Quartz is ubiquitous in country rock and stream sediments but was not identified as a discrete phase in the SEM study. At the operating voltage used, the EDS spectra reflect the composition of a sample volume on the order of 4 to $6 \mu \mathrm{m}^{3}$, so the quartz is either very fine-grained or the silicon is an integral component of the aluminum hydroxysulfate phase. Upon heating from 22 to $900{ }^{\circ} \mathrm{C}$ (Fig. $8 \mathrm{~b}$ ), the white precipitate loses $46 \%$ of the starting sample mass as water; most of this water $(30 \%)$ evolves in an endothermal event around $105^{\circ} \mathrm{C}$. A high temperature $\left(940{ }^{\circ} \mathrm{C}\right)$ mass loss of an additional $3.5 \mathrm{wt} \%$ reflects sulfate loss.

\section{Efflorescent salts}

Alum Cave represents an unusual occurrence of a large variety of secondary sulfate minerals, including the first reported occurrence of slavikite in North America (Lauf 1997) and new rare-earth oxalate minerals and phosphate minerals (Peacor and others 1999a, 1999b; Rouse and others 2001). Secondary sulfate minerals reported to date from Alum Cave and from other localities in and near Great Smoky Mountains National Park are listed in Table 4, including new data from this study. The ephemeral nature of most of these minerals (due to their high solubility) makes them difficult to collect. The particular salts that form at any spot are a function of local solution composition, $\mathrm{pH}$, and relative humidity. Jambor and others (2000) reviewed metal-sulfate salts from sulfide mineral oxidation and noted that these minerals, which play an important role in trace metal cycling between aqueous and solid solutions, can be overlooked.

During site visits in both 1997 and 1998, salts were present at Alum Cave and along the Road-to-Nowhere. The host rock at Alum Cave is very friable and sooty slate; salts locally form crusts as much as $1 \mathrm{~cm}$ thick along cleavages and partings. Flohr and others (1995) described a number of different textures of secondary mineral development at Alum Cave and showed that copiapite, halotrichite, slavikite, melanterite, and rozenite are the minerals that form relatively thick encrustations. The salts that were sampled at Alum Cave in 1997 and 1998 include yellowish green clusters of slavikite (Fig. 9), yellow copiapite, salmon pink to pale orange halotrichite-group minerals, and variety of white salts including rozenite, epsomite, and hexahydrite mixed with pickeringite-halotrichite hair salts. The weather conditions during the September 1998 visit (hot, dry, relative humidity of $14 \%$ ) favor rozenite as the most stable ferrous iron hydroxysulfate mineral (Chou and others 2002). In a field experiment, a $2.1 \mathrm{~g}$ sample of mostly green salts (slavikite) readily dissolved in $20 \mathrm{~mL}$ of deionized water; solution $\mathrm{pH}$ dropped from 6.8 to 2.8 instantaneously. Within $10 \mathrm{~min}$, the pea green solution turned orange, which suggests that dissolved ferric iron rapidly hydrolyzed and precipitated as a ferric oxyhydroxide in an acid-generating reaction:

$$
\mathrm{Fe}^{3+}+3 \mathrm{H}_{2} \mathrm{O} \rightarrow \mathrm{Fe}(\mathrm{OH})_{3(\text { solid })}+3 \mathrm{H}^{+}
$$

The same experiment performed on white and yellow salts (rozenite, halotrichite-group minerals) yielded a slightly 

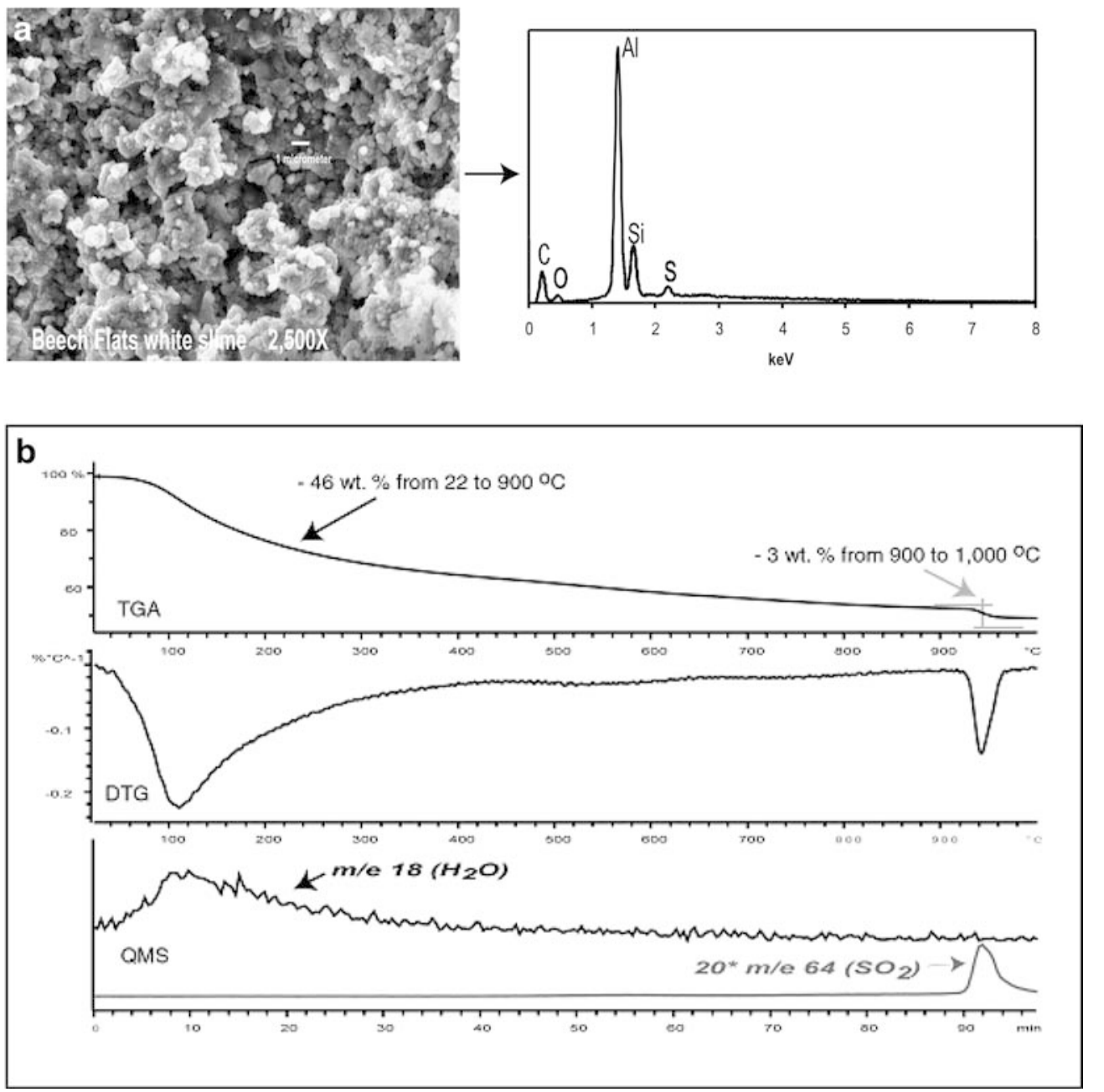

Fig. 8

Aluminum-rich white precipitate along Beech Flats Creek. a Secondary electron SEM image and EDS spectra. b TGA, DTG, and mass spectral traces (QMS) from simultaneous evolved gas analysis show that the material loses almost half (46 wt\%) its mass in water. Most of the water comes off at about $100{ }^{\circ} \mathrm{C}$, but water loss continues gradually at higher temperatures. Sulfate is evolved in a sharp thermal event at about $925{ }^{\circ} \mathrm{C}$ and accounts for about $3 \mathrm{wt} \%$ of the total sample. The $10 \mathrm{mg}$ sample was heated from 22 to $1,000^{\circ} \mathrm{C}$ in an alumina crucible at a rate of $10{ }^{\circ} \mathrm{C} / \mathrm{min}$ in an argon atmosphere

Table 3

Water chemistry for Beech Flats Creek. Selected data analyzed by ICP-MS; sulfate analyzed in USGS laboratories in Ocala, FL by ion chromatography; $R A$ unfiltered water; $F A$ water filtered through $0.45 \mu \mathrm{m}$ nitrocellulose filters

\begin{tabular}{|c|c|c|c|c|c|c|c|c|c|c|}
\hline $\begin{array}{l}\text { Location relative } \\
\text { to roadfill dump }\end{array}$ & Sample & $\mathrm{pH}$ & $\begin{array}{l}\text { Cond. } \\
(\mu \mathrm{S} / \mathrm{cm})\end{array}$ & $\mathrm{Al}(\mu \mathrm{g} / \mathrm{L})$ & $\mathrm{Fe}(\mu \mathrm{g} / \mathrm{L})$ & $\begin{array}{l}\mathrm{Mn} \\
(\mu \mathrm{g} / \mathrm{L})\end{array}$ & $\begin{array}{c}\mathrm{SO}_{4} \\
(\mathrm{mg} / \mathrm{L})\end{array}$ & $\begin{array}{l}\mathrm{Cu} \\
(\mu \mathrm{g} / \mathrm{L})\end{array}$ & $\mathrm{Pb}(\mu \mathrm{g} / \mathrm{L}$ & $\begin{array}{l}\mathrm{Zn} \\
(\mu \mathrm{g} / \mathrm{L})\end{array}$ \\
\hline \multirow[t]{2}{*}{ Upstream } & BCFT-1-3 RA & 6.2 & 25 & 120 & 100 & 11 & 3.6 & 0.8 & 0.06 & 3 \\
\hline & BCFT-1-3 FA & - & - & $<0.01$ & 14 & 0.21 & 3.4 & $<0.5$ & $<0.05$ & 1 \\
\hline \multirow{6}{*}{$\begin{array}{l}\text { Downstream } \\
(1-2 \mathrm{~m})\end{array}$} & BCFT-2-3 RA & 5.8 & 34 & 200 & 68 & 92 & 6.9 & 0.6 & $<0.05$ & 30 \\
\hline & BCFT-2-3 FA & - & - & 15 & 43 & 92 & 6.5 & $<0.5$ & $<0.05$ & 30 \\
\hline & BCFT-3-3 RA & 4.6 & 44 & 780 & 89 & 160 & 13 & 4 & 0.07 & 35 \\
\hline & BCFT-3-3 FA & - & - & 300 & 20 & 160 & 13 & 1 & $<0.05$ & 34 \\
\hline & BCFT-4-3 RA & 5.2 & 39 & 4500 & 300 & 140 & 11 & 2 & 0.50 & 30 \\
\hline & BCFT-4-3 FA & - & - & 220 & 16 & 110 & 11 & 0.6 & $<0.05$ & 28 \\
\hline \multirow{2}{*}{ Far downstream } & BCFT-5-3 RA & 6.2 & 30 & 17 & 22 & 3.0 & 7.7 & $<0.5$ & $<0.05$ & 4 \\
\hline & BCFT-5-3 FA & - & - & $<0.01$ & 14 & 0.74 & 8.1 & $<0.5$ & $<0.05$ & 4 \\
\hline
\end{tabular}

higher paste $\mathrm{pH}$ of 3.3. Many of the unusual minerals at Alum Cave, including the new rare-earth oxalate minerals, occur in the soil at the base of the bluff or are embedded in other salts (Peacor and others 1999a, 1999b; Coskren and Lauf 2000).

White salts coating a gossan crust developed on bedrock exposed in the Anakeesta Ridge debris flow scar (Fig. 6) were identified as the highly soluble ferrous iron sulfate mineral rozenite. In contrast to the protected overhang at Alum Cave where relatively soluble minerals persist and build up crusts over time, any salts that form in the open setting of the debris flow scar are likely to dissolve and reform on short-term cycles. Salts coating the bedrock surface provide a local source of iron for the ochres forming in the channel below the scar.

The Road-to-Nowhere salt outcrop is much smaller in scale than Alum Cave. The most common salt is pickeringite (Fig. 9), and salts tend to be more magnesian in overall composition. The host rock (Wehutty Formation) is a higher metamorphic grade (kyanite) than the Anake- 
Table 4

Secondary minerals. References: 1 This study; 2 Flohr and others 1995; 3 Coskren and Lauf 2000; 4 Peacor and others 1999 a; 5 Peacor and others 1999b; 6 Rouse and others 2001

\begin{tabular}{|c|c|c|c|c|}
\hline Mineral & Ideal formula & Alum Cave & Road-to-Nowhere & Debris flows \\
\hline Alunogen & $\mathrm{Al}_{2}\left(\mathrm{SO}_{4}\right)_{3} \cdot 17 \mathrm{H}_{2} \mathrm{O}$ & $1,2,3$ & - & - \\
\hline Amorphous aluminum sulfate & - & - & - & 1 \\
\hline Apjohnite & $(\mathrm{Mn}, \mathrm{Mg}) \mathrm{Al}_{2}\left(\mathrm{SO}_{4}\right)_{4} \cdot 22 \mathrm{H}_{2} \mathrm{O}$ & 3 & - & - \\
\hline Basaluminite & $\mathrm{Al}_{4}\left(\mathrm{SO}_{4}\right)(\mathrm{OH})_{10} \cdot 5 \mathrm{H}_{2} \mathrm{O}$ & 3 & - & - \\
\hline Botryogen & $\mathrm{MgFe}^{3+}\left(\mathrm{SO}_{4}\right)_{2}(\mathrm{OH}) \cdot 7 \mathrm{H}_{2} \mathrm{O}$ & 3 & - & - \\
\hline Destinezite & $\mathrm{Fe}_{2}\left(\mathrm{PO}_{4}\right)\left(\mathrm{SO}_{4}\right)(\mathrm{OH}) \cdot 6 \mathrm{H}_{2} \mathrm{O}$ & 3,4 & - & - \\
\hline Epsomite & $\mathrm{MgSO}_{4} \cdot 7 \mathrm{H}_{2} \mathrm{O}$ & 2,3 & 1 & - \\
\hline Gypsum & $\mathrm{CaSO}_{4} \cdot 2 \mathrm{H}_{2} \mathrm{O}$ & $1,2,3$ & 1 & 1 \\
\hline Hexahydrite & $\mathrm{MgSO}_{4} \cdot 6 \mathrm{H}_{2} \mathrm{O}$ & 3 & - & - \\
\hline Halothrichite & $\mathrm{FeAl}_{2}\left(\mathrm{SO}_{4}\right)_{4} \cdot 22 \mathrm{H}_{2} \mathrm{O}$ & $1,2,3$ & 1 & - \\
\hline Hydronium jarosite & $\mathrm{H}_{3} \mathrm{O}^{+} \mathrm{Fe}^{3+}{ }_{6}\left(\mathrm{SO}_{4}\right)_{4}(\mathrm{OH})_{12}$ & 2 & 1 & - \\
\hline Rozenite & $\mathrm{FeSO}_{4} \cdot 4 \mathrm{H}_{2} \mathrm{O}$ & $1,2,3$ & - & 1 \\
\hline Schwertmannite & $\mathrm{Fe}^{3+}{ }_{16} \mathrm{O}_{16}(\mathrm{OH})_{12}\left(\mathrm{SO}_{4}\right)_{2}$ & 3 & - & 1 \\
\hline Slavikite & $\mathrm{NaMg}_{2} \mathrm{Fe}_{5}^{3+}\left(\mathrm{SO}_{4}\right)_{7}(\mathrm{OH})_{6} \cdot 33 \mathrm{H}_{2} \mathrm{O}$ & $1,2,3$ & - & - \\
\hline Starkeyite & $\mathrm{MgSO}_{4} \cdot 4 \mathrm{H}_{2} \mathrm{O}$ & 2 & - & - \\
\hline Tschermigite & $\left(\mathrm{NH}_{4}\right) \mathrm{Al}\left(\mathrm{SO}_{4}\right)_{2} \cdot 12 \mathrm{H}_{2} \mathrm{O}$ & 3 & - & - \\
\hline Zugshunstite-(Ce) & $(\mathrm{Ce}, \mathrm{Nd}, \mathrm{La}) \mathrm{Al}\left(\mathrm{SO}_{4}\right)_{2}\left(\mathrm{C}_{2} \mathrm{O}_{4}\right) \cdot 12 \mathrm{H}_{2} \mathrm{O}$ & $3,5,6$ & - & - \\
\hline
\end{tabular}

esta Formation at Alum Cave (garnet grade). At a number of other outcrops along the road at groundwater seeps, rock faces are stained yellow by jarosite and gypsum crystals that form millimeter-scale stalactites hanging from rock ledges.

Solution composition from a leaching experiment conducted on sulfidic mine waste at the Hazel Creek mine is given in Table 5, along with leachate compositions from dissolution experiments on composite salt samples from Alum Cave and the Road-to-Nowhere reported by Hammarstrom and others (2000). In the mine waste leachate, readily soluble zinc $(1,300 \mu \mathrm{g} / \mathrm{L})$ exceeds copper $(590 \mu \mathrm{g} / \mathrm{L})$ and lead $(190 \mu \mathrm{g} / \mathrm{L})$. Aluminum, iron, manganese, magnesium, copper, zinc, and sulfate are the dominant dissolved species in leachate for both salt samples. Some rare-earth element concentrations $(\mathrm{Ce}, \mathrm{La}, \mathrm{Nd})$ are an order of magnitude higher in Alum Cave salt leachates, consistent with the reported occurrences of rare-

earth-bearing secondary minerals at the site. The contrast between leachate from oxidized surface mine waste and leachate from salts is remarkable because the copper concentrations in the salt leachates are higher $(900 \mu \mathrm{g} / \mathrm{L}$ or more) than in the copper mine waste leachate $(590 \mu \mathrm{g} / \mathrm{L})$. Although the absolute metal concentrations are not significant, these data indicate that secondary minerals that form naturally at weathering sulfidic rocks outcrops have the potential to impact aquatic ecosystems with metal concentrations comparable to, or in excess of, metals from mine waste. The Alum Cave salts are also a source of readily available arsenic. Host-rock weathering involves dissolution of accessory mineral phases, such as zircon and allanite, and these minerals are probably the source of the rare-earth elements as well as uranium. Flohr and others (1995) identified Mn-rich garnet, zircon, rutile, pyrite, pyrrhotite, allanite, monazite, and apatite in slaty rocks of the Anakeesta Formation at Alum Cave.

\section{Stream sediments}

Selected stream-sediment geochemical data are given in Table 6, along with reference values. Samples are arranged by locality. Within a given geographic area, samples are listed from upstream to downstream. For example, at Road Prong (Fig. 3, localities 11-13), sample RP-1-SS was collected upstream of the 1996 debris flow, sample RP-2-SS was collected just below the debris flow, and sample NPS-72-SS was collected $2 \mathrm{~km}$ downstream from the debris flow. Similarly, samples were collected upstream of the mine workings at the Fontana and Hazel Creek mines. Sample site descriptions, complete chemical data, and associated water data are available as online supplemental data (Tables ESM 2, ESM 3, and ESM 4). Surface waters in the mine areas are all near-neutral $(\mathrm{pH}>6.3)$. The most acidic waters $(\mathrm{pH}<5)$ at the stream sediment sampling sites are those in the Alum Cave area. The fine fractions $(<80$ mesh) that were analyzed comprise 2 to $20 \%$ of the total ( $1 \mathrm{~kg}$ or more of $<10$ mesh sediment) sample mass collected; samples that contain the highest percentages of fines are those from the copper mine areas in the southern part of the park. XRD shows that the dominant minerals in all these sediments are quartz, white mica, chlorite, feldspar; minor (approximately 5\%) to trace amounts of pyrite are identified in about half of the samples. These minerals do not account for the elevated iron and manganese contents of many of 


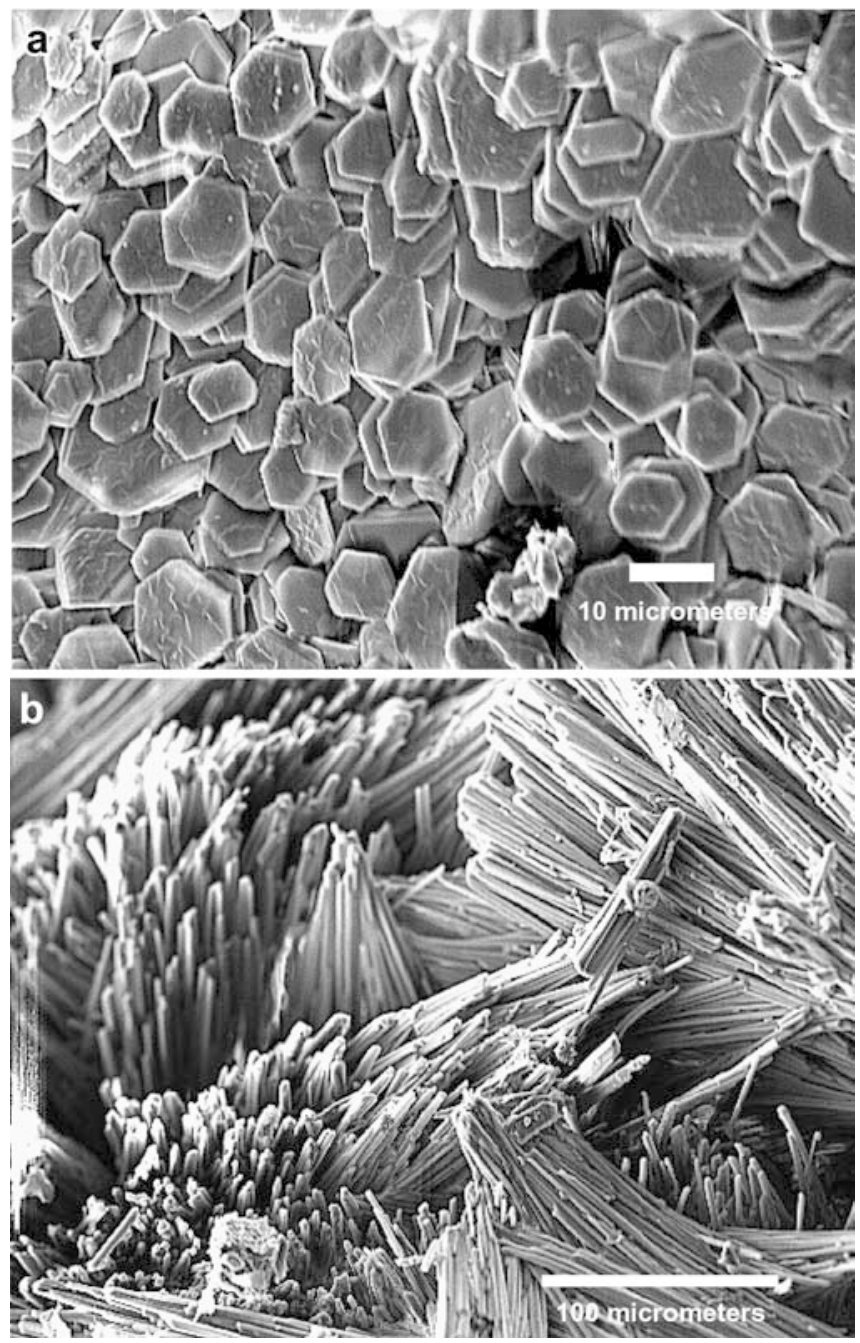

Fig. 9

Secondary-electron images of efflorescent sulfate salts. a Slavikite from Alum Cave. b Pickeringite along the Road-to-Nowhere

the samples; poorly crystalline to amorphous iron and manganese oxyhydroxide phases in the fine-grained sediments account for this discrepancy.

The highest base-metal concentrations (up to 1\%) in stream sediments within the study area occur in the streams that drain copper mines, where $\mathrm{Cu}>\mathrm{Zn}>\mathrm{Pb}$. Samples from background areas above mine workings or along adjacent streams unaffected by mining (Fig. 3, localities $16,19,20,23$ ) have total base-metal concentrations $<200 \mathrm{mg} / \mathrm{kg}$. The highest copper concentration $(10,200 \mathrm{mg} / \mathrm{kg})$ of the data set was measured for a 1997 sample from the edge of the Eagle Creek arm of Fontana Lake closest to the Fontana mine. The 1998 composite lakeshore surface sediment (FM-98-SS-3), sampled when the lake level was lower, had $852 \mathrm{mg} / \mathrm{kg}$ copper at the surface and $1,510 \mathrm{mg} / \mathrm{kg}$ copper at $20 \mathrm{~cm}$ depth (FM-SS98-2). In other areas of the park, total base metals locally exceed $200 \mathrm{mg} / \mathrm{kg}$; in all such cases, zinc concentrations exceed copper and lead concentrations.

Stream sediment geochemical data (Table 6) are compared with crustal abundance values, expressed as Clarke Index values (Fortescue 1992), and average global compositions
Table 5

Leachate water chemistry for mine waste and salts. ICP-MS data on filtered $(0.45 \mu \mathrm{m})$ 24-h leachates

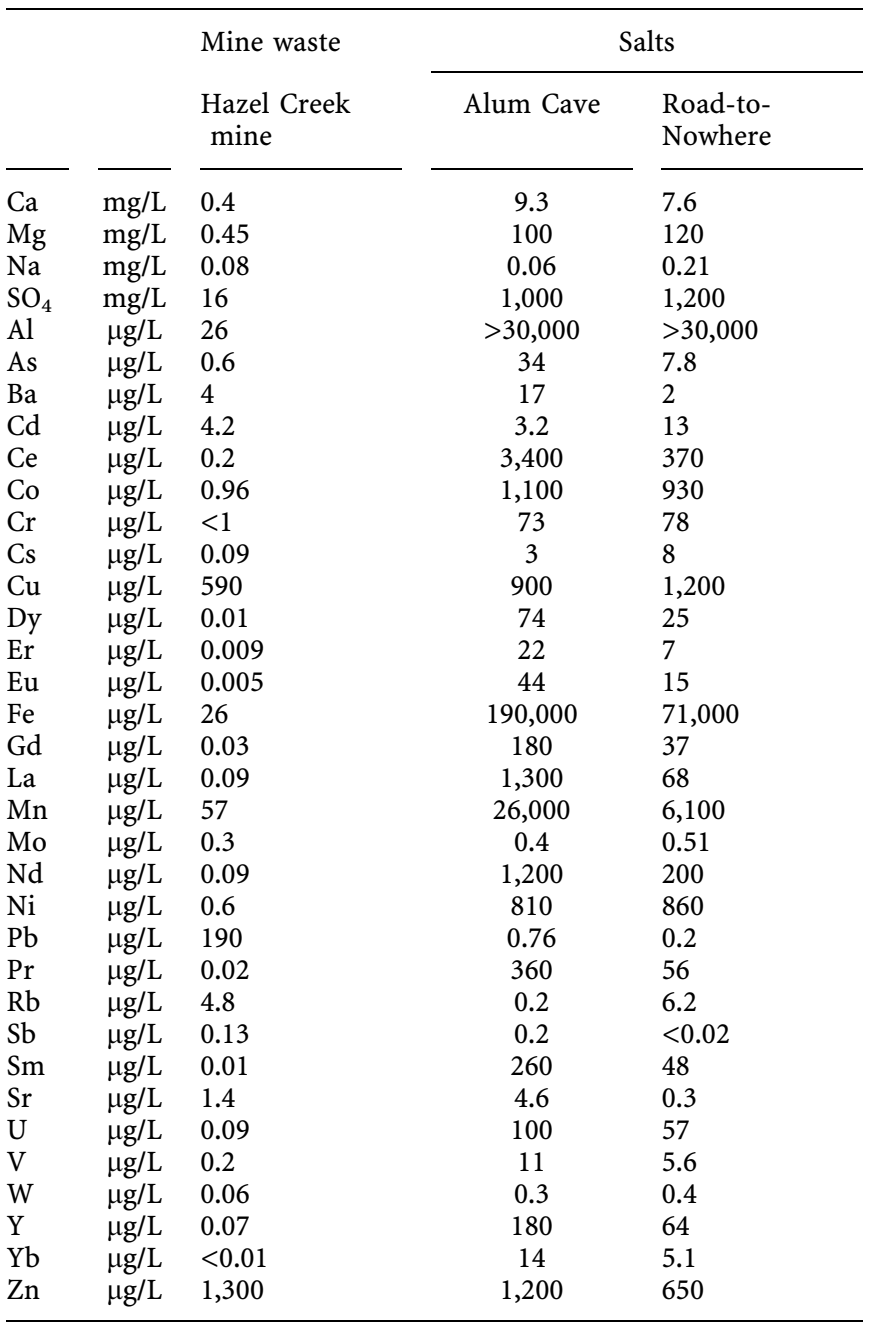

for the most abundant lithologies in the study area (Krauskopf 1979). Contaminated stream sediments can affect aquatic ecosystems and human health because of their potential toxicity to benthic organisms and to humans who ingest organisms exposed to contaminated sediments (US EPA 1997). Sediments can serve as sources or sinks for heavy metals. The use of stream sediment data for aquatic life toxicity assessment is controversial and cannot substitute for bioassay toxicity data; different sediments can represent different degrees of bioavailability for the same total concentration of a trace metal (Di Toro and others 1990). Nevertheless, stream sediment data provide a useful screening tool for identifying areas that may warrant more costly and time-consuming field toxicity studies. MacDonald and others (2000) proposed consensus-based stream sediment quality guidelines for 28 metals and organic compounds for freshwater ecosystems. Consensus-based guidelines are based on criteria previously developed from comparisons of sediment chemistry with toxicity data collected in field studies. Two consensus-based values are reported for each potential contaminant: (1) the threshold effect concentration (TEC) 


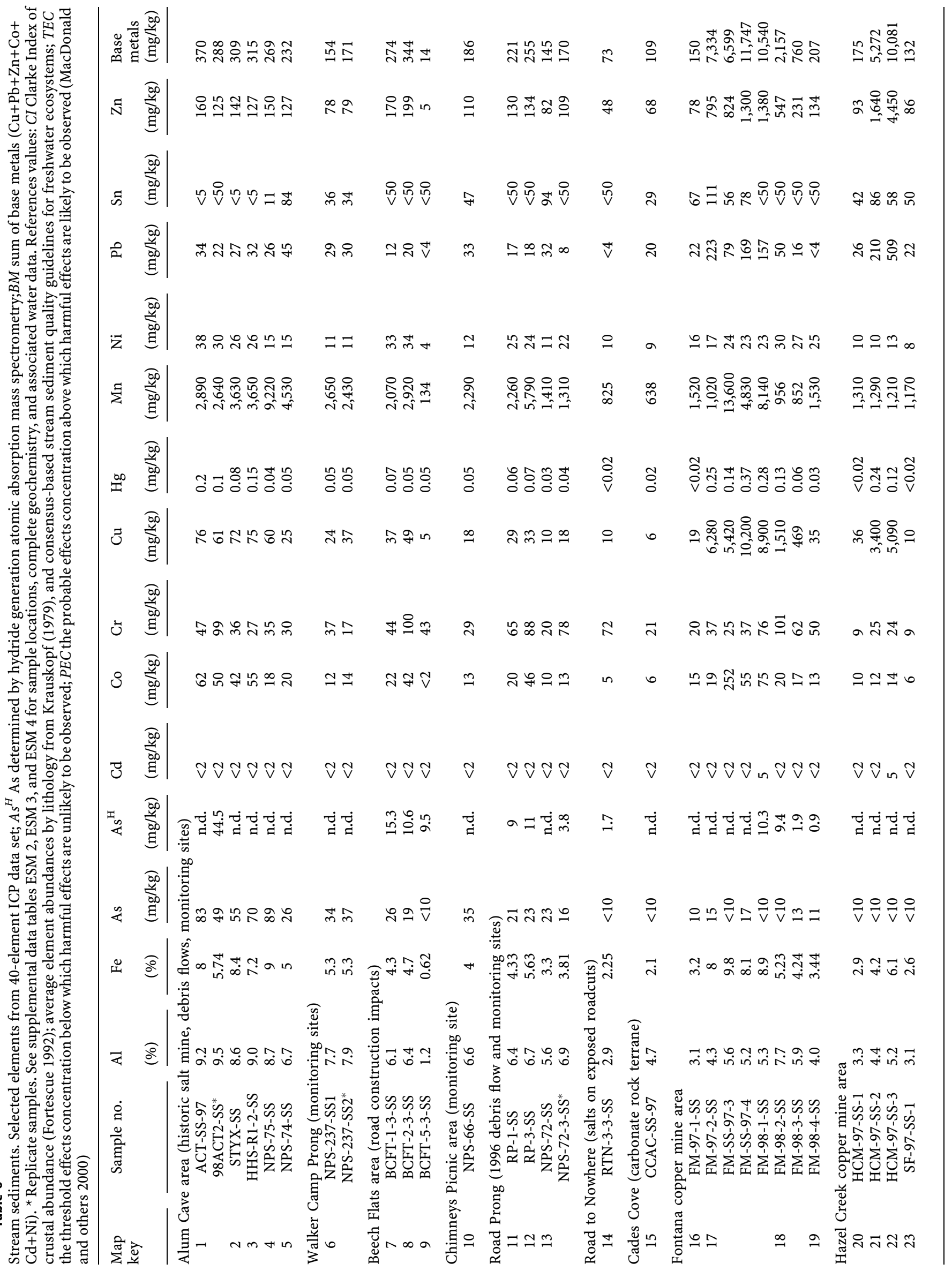




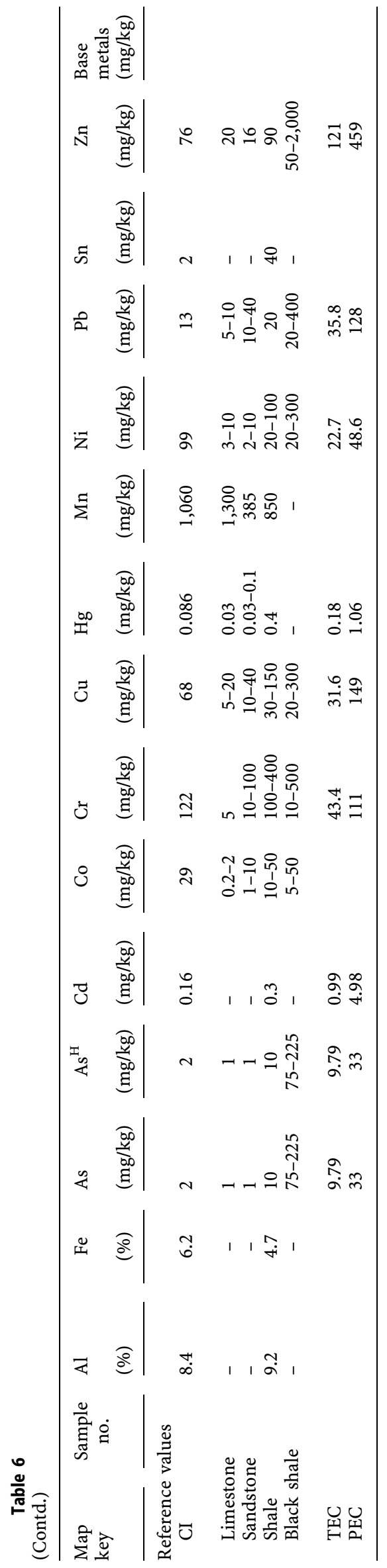

is the concentration below which harmful effects are unlikely to be observed and (2) the probable effects concentration (PEC) is the concentration above which harmful effects are likely to be observed.

The distribution of selected metals in stream sediments is plotted on a map of the park in Fig. 10 in terms of concentration ranges based on stream sediment quality criteria.

In the small streams that drain the mine areas, probable effects levels are exceeded for copper, zinc, lead, and cadmium (Table 6). No samples exceeded probable effects concentrations for mercury. Arsenic exceeds probable effects concentrations in the Alum Cave area and Walker Camp Prong (Fig. 10; Table 6); sediments from these areas typically contain three times more arsenic than sediments from the mine areas. For the 12 samples where arsenic was determined by both ICP-AES and the more sensitive hydride method, the ICP-AES concentrations exceed hydride concentrations in all cases, by a factor of 2 to 12 . In cases where ICP-AES arsenic values are below the detection limit $(<10 \mathrm{mg} / \mathrm{kg})$, hydride arsenic values are $10 \mathrm{mg} /$ $\mathrm{kg}$ or less. In the Alum Cave area where arsenic concentrations measured by ICP-AES typically exceed PECs, the one sample analyzed by the hydride method also exceeds the PEC.

\section{Discussion}

Environmental signature of copper mines

The Fontana and Hazel Creek mines exploited Besshi-type massive sulfide deposits (Robinson and others 1992; Seal and others 2002). Historic mining of these types of deposits elsewhere typically led to significant environmental impacts because (1) the ores are massive accumulations of iron- and other metal-bearing sulfide minerals that release acid and metals upon oxidative weathering and (2) the host-rock lithologies for these deposits typically lack significant amounts of carbonate minerals that could provide natural acid neutralization (Seal and others 2000, 2002). In the case of the two mines in Great Smoky Mountains National Park, however, surface impacts appear to be limited compared to many other sites such as Ducktown, Tennessee, because Fontana mine ores were shipped off-site for processing. The lack of development of acid mine drainage affecting streams that drain the mines is due to several factors: (1) very little mine waste and exposed ore material was left on-site at closure of the Fontana and Hazel Creek mines in the 1950s, (2) the contribution of acidic effluent from flooded underground workings to the streams that flow past the workings is very low, and (3) extremely high amounts of annual precipitation (on the order of 150 to $200 \mathrm{~cm}$ per year) effectively dissolve soluble secondary minerals that may form on exposed mine waste during dry periods and dilute downstream effects. Also, the dominant sulfide mineral in the ores is pyrrhotite $\left(\mathrm{Fe}_{1-\mathrm{x}} \mathrm{S}\right)$ rather than pyrite $\left(\mathrm{FeS}_{2}\right)$. Pyrite, which is the dominant iron sulfide mineral in other types of massive sulfide deposits and the dominant iron sulfide 


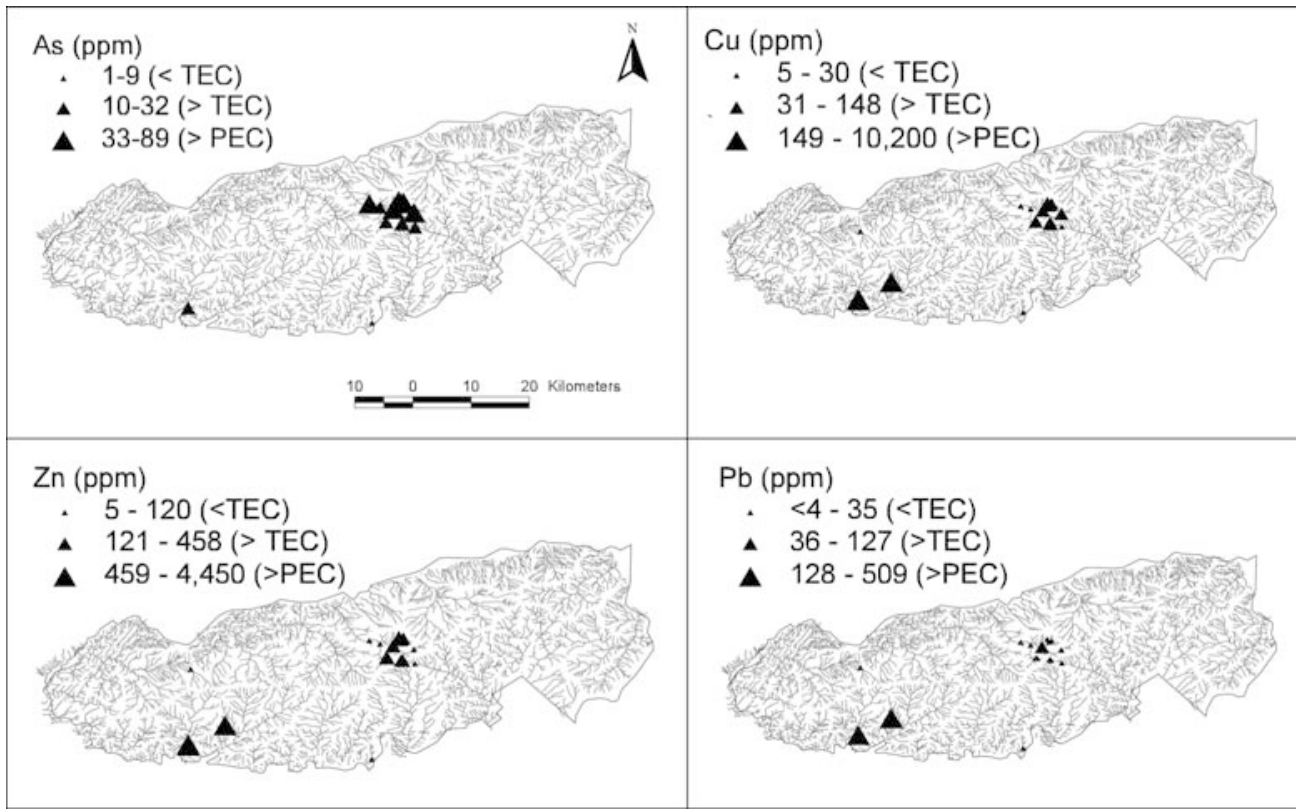

Fig. 10

Selected metal distributions in $<80$ mesh stream sediments in Great Smoky Mountains National Park. Graduated symbols represent concentration ranges grouped by consensus-based stream sediment quality guidelines (MacDonald and others 2000).TEC Threshold effects concentration. PEC Probable effects concentration mineral disseminated throughout rocks of the Anakeesta Formation, generates significant acid upon oxidation. Pyrrhotite can oxidize without generating significant acid because pyrrhotite has approximately half the sulfur of pyrite (Seal and others 2000). Marcasite, however, is an intermediate weathering product of pyrrhotite oxidation in gossan at the Fontana and Hazel Creek mines (Flohr and Hammarstrom 1997). Oxidation of marcasite, a dimorph of pyrite, as well as oxidation of pyrrhotite by ferric iron instead of oxidation by dissolved oxygen contribute to the development of extremely acidic waters ponded within the underground mine workings. Mine-area stream waters locally exceed hardness-adjusted acute toxicity criteria for freshwater aquatic ecosystems for some metals, but the impact of the streams on Fontana Lake is minimal (Seal and others 1998).

At the Fontana mine, vegetation is re-established around the mine workings. At the Hazel Creek mine, waste dumps remain barren 54 years after mining ceased. The net neutralization potential of the Hazel Creek mine waste sample was measured as $-61 \mathrm{~kg}$ of $\mathrm{CaCO}_{3}$ equivalent per metric ton ( -65 tons of $\mathrm{CaCO}_{3}$ equivalent per 1,000 short tons), based on sulfide sulfur, which includes contributions from non-acid-generating sulfide minerals such as chalcopyrite and sphalerite as well as acid-generating iron sulfide minerals. Sulfate sulfur reflects insoluble minerals such as barite and the relatively insoluble mineral gypsum, as well as potentially acid-producing soluble iron sulfate salts. Acid-base accounting is a controversial engineering approach to classifying different types of materials; different methods yield different results and the mineralogy of the material tested significantly affects test results.

Although the mine waste is classified as acid generating by acid-base accounting and would require mitigation for successful vegetation, surface waters downstream from the workings are rapidly diluted to near-neutral values (Seal and others 1998).
During characterization of Anakeesta-type pyritic bedrock along the Ocoee River in Polk County Tennessee for construction of the Olympic whitewater venue, acid-base accounting was used as a preliminary screening tool to measure the acid-generating potential of materials that could be involved in site excavation (Byerly 1994). That study showed that pyritic lithologies (argillite, metagreywacke, metasandstone and metasiltstone) at the site contained as much as $2 \mathrm{wt} \%$ total sulfur; net neutralization potential values ranged from -68 (comparable to Hazel Creek mine waste) to +109 tons of $\mathrm{CaCO}_{3}$ equivalent per 1,000 short tons of rock. Differences in acid-base accounting methods, laboratories, and mineralogy affect test results, but the point is that the Anakeesta Formation in areas away from mineral deposits can pose acidgenerating problems comparable to mine waste sources. Therefore, water- and sediment-quality guidelines may be difficult to achieve because of elevated natural background concentrations, especially for metals such as zinc and copper, which tend to mobilize at low $\mathrm{pH}$.

Ochre precipitating at an iron bog forming at the base of a groundwater seep contributes fine-grained, metal-rich sediment to the stream that flows past the Fontana mine. Sorption of metals onto ochre minerals improves water quality by removing heavy metals from solution; however, these minerals become part of the sediment where they may impact benthic organisms. Stream sediment basemetal concentrations in the streams that flow past the mine workings exceed probable effects concentrations for freshwater ecosystems (Table 6). Concentrations increase by two orders of magnitude relative to backgrounds measured upstream from the mines and along adjacent streams that drain unmined areas (Fig. 11). The highest base-metal concentrations in sediment $(11,747 \mathrm{mg} / \mathrm{kg}$ total base metals) were measured in a 1997 sample collected just offshore of the high water level of the Eagle Creek arm of Fontana Lake. In 1998, when the lake level was lower by 

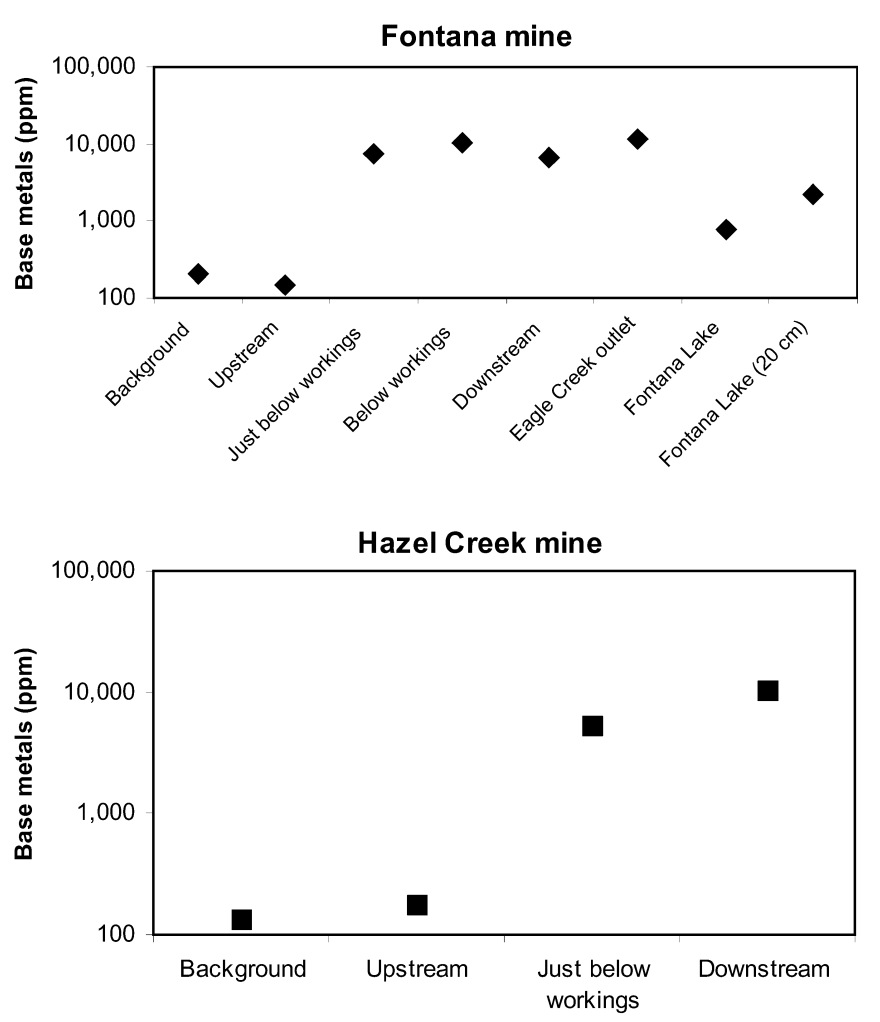

Fig. 11

Base-metal concentration trends in fine-grained $(<0.177 \mathrm{~mm})$ stream sediments in ephemeral streams draining inactive copper mines. Background samples are from adjacent streams that drain unmined areas

more than $20 \mathrm{~m}$, sediment sampled at the lake edge contained $760 \mathrm{mg} / \mathrm{kg}$ total base metals. Base-metal concentrations in sediment from $20 \mathrm{~cm}$ depth at the same location are almost three times greater $(2,157 \mathrm{mg} / \mathrm{kg})$ than the surface sediment. In all cases, copper $>$ zinc $>$ lead. Abernathy and others (1984) showed that Fontana Lake sediments (sampled throughout the lake in 1978) contained elevated manganese, copper, and zinc compared to sediments from some polluted areas and that sediments from the Eagle Creek and Hazel Creek arms of Fontana Lake contained elevated copper relative to other lake sediments. They attributed the lake sediment signature to geological sources of pyritic material in the Anakeesta Formation, and locally, from the mine areas. The data in this study are not directly comparable to the Abernathy data set because the authors of the present study sampled shallower lake depths, worked with sized materials, and used different sampling and analytical techniques.

Effects of natural weathering on stream sediments Base-metal concentrations in fine-grained fractions of stream sediments away from mine areas typically are on the order of 100 to $300 \mathrm{mg} / \mathrm{kg}$ (Table 6). Metal concentrations in sediments that drain carbonate rocks in the Cades Cove area are all below sediment guideline threshold effects concentrations (Fig. 10). In contrast, sediments that drain Anakeesta Formation locally exceed threshold effects guidelines for copper, zinc, and arsenic. Total
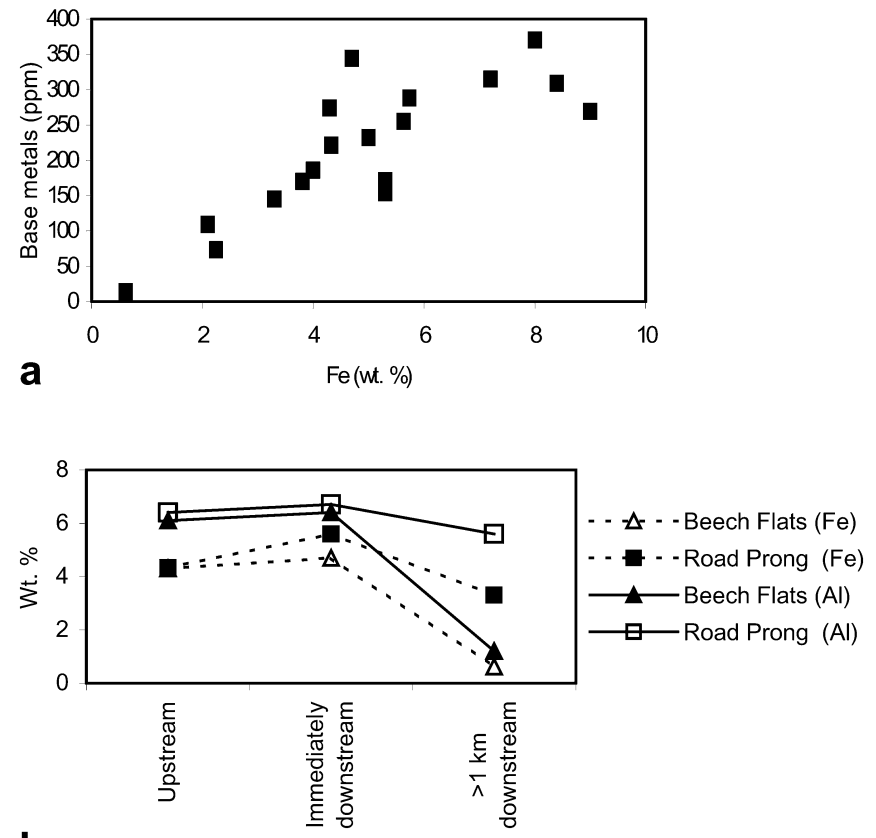

b Location relative to disturbed area

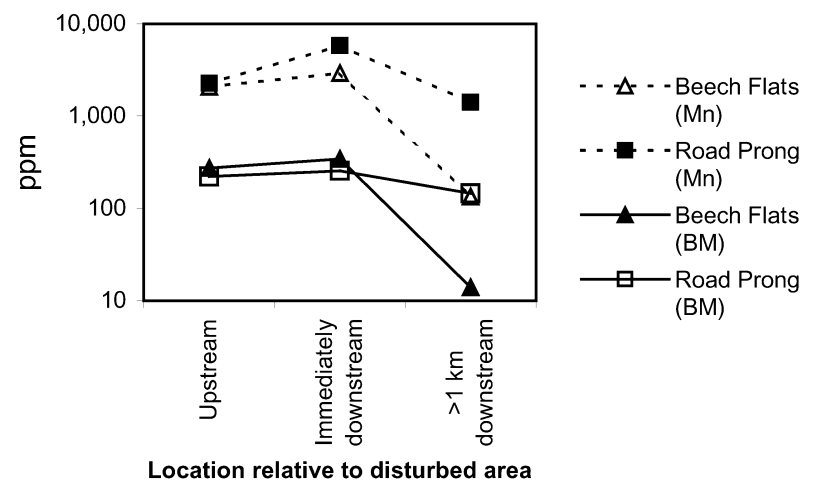

Fig. 12

Concentrations of metals in fine-grained $(<0.177 \mathrm{~mm})$ stream sediments away from mined areas. a Total base metal

$(\mathrm{Cu}+\mathrm{Pb}+\mathrm{Zn}+\mathrm{Co}+\mathrm{Cd}+\mathrm{Ni})$ vs iron content. $\mathbf{b} \mathrm{Fe}$ and $\mathrm{Al}$ concentrations in stream sediments upstream, immediately downstream, and far downstream from human-induced (roadfill at Beech Flats) and natural (debris flow at Road Prong) disturbances to Anakeesta Formation.c Manganese and total base metal concentrations (log scale) along the same stream gradient plotted in $\mathbf{b}$

base-metal concentrations tend to increase with increasing sediment iron content (Fig. 12a); this relationship can be explained by detrital sulfide minerals or by sorption of metals onto ochre minerals.

In a study of contamination of trout streams by exposed Anakeesta Formation, Bacon and Maas (1979) showed that zinc and manganese concentrations increased along Beech Flats Creek due to the road construction disturbances of bedrock. Sediment data collected 22 years later (Table 6) show that the roadfill material continues to contribute iron, aluminum, manganese, and base metals to sediments immediately downstream (Fig. 12b, c). Concentrations of all these metals increase slightly relative to the upstream sample site, and then decrease dramatically at a far downstream sample site, where precipitates drop off and 
side streams contribute sediment that can dilute the metal signature. Kucken and others (1994) showed that although Beech Flats Creek recovers far downstream $(>7 \mathrm{~km})$ from the roadfill site, water quality, benthic macro-invertebrate, salamander larvae, and fish populations had not recovered in the 15 -year period following contamination. Sediment sampling immediately upstream and downstream of the 1996 Road Prong debris flow (Fig. 12b, c) shows similar patterns and absolute metal concentrations to the Beech Flats area. Alum Cave Creek is affected by numerous historic debris flows. Manganese concentrations in stream sediments along Alum Cave Creek increase twofold to threefold between the upstream (Fig. 3, localities 1-3) and downstream (Fig. 3, locality 4) sites. Sediment from the bottom of a pool formed by seepage from Huggins Hell debris flow (Fig. 3, locality 3) however, is chemically indistinct from the other samples in the area.

Foley and others (2001) showed that weathering of metalbearing sulfide minerals in Anakeesta Formation produces alteration minerals of varying degrees of stability, including marcasite alteration of pyrrhotite, covellite, and a variety of metal oxyhydroxide, hydroxide, and sulfate minerals. Their study of the geochemistry of metamorphosed black shales in the area of Great Smoky Mountains National Park included samples of Anakeesta Formation that contained 41 to $78 \mathrm{wt} \% \mathrm{SiO}_{2}, 1$ to $10 \mathrm{wt} \%$ iron as $\mathrm{Fe}_{2} \mathrm{O}_{3}, 10$ to $28 \mathrm{wt} \% \mathrm{Al}_{2} \mathrm{O}_{3}$, and $<1$ to $77 \mathrm{mg} / \mathrm{kg}$ arsenic and $<2$ to $105 \mathrm{mg} / \mathrm{kg}$ copper. Arsenic, in particular, is elevated in parts of the Anakeesta Formation relative to average shale, which ranges from $<1$ to $50 \mathrm{mg} / \mathrm{kg}$ arsenic.

\section{The role of secondary minerals in metal sequestration}

Exposure of fresh surfaces of pyritic rock to air and water by any means (debris flow, construction, mining) promotes acid generation and metal mobility in surface runoff. Soluble secondary minerals, such as the many salts at Alum Cave and along the Road-to-Nowhere and the rozenite coating the Anakeesta Ridge debris flow scar, temporarily sequester iron, other metals, and acidity. Dissolution of these minerals during storm events can dramatically alter surface water chemistry with catastrophic, short-term effects (Dagenhart 1980). Fe, Al, Mg, and $\mathrm{Mn}$ are the major constituents of the soluble secondary minerals observed forming on pyritic rocks of the Anakeesta Formation, along with minor amounts of copper, zinc, and other elements (Table 4).

The ochre deposits that form when amorphous to poorly crystalline iron, aluminum, or manganese minerals precipitate are important because they can scavenge dissolved trace elements by sorption or coprecipitation and therefore affect water quality. $\mathrm{pH}$ is a master variable that controls the nature of the ochre minerals precipitated as well as the nature of sorbed elements and the efficiency of sorption.

Ochre was not observed precipitating in the streams that flow past the Fontana and Hazel Creek mines during this study. Cemented hardpan layers are present along the Eagle Creek headwaters that flow past the Fontana mine; ochre muds that dry to hardpan terraces and stalactites are actively forming from groundwater seeping into the underground workings at both mines. Manganese-rich ochre that incorporates about $1 \mathrm{wt} \%$ copper and $0.1 \mathrm{wt} \%$ zinc (Table 2) is actively precipitating from an iron bog at a near-neutral, oxidized groundwater seep alongside the creek. During high flow, this material can enter the creek as sediment. In contrast to the mine areas, small deposits of ochre that mimic acid-mine drainage are actively precipitating where groundwater and surface runoff interact with pyritic rocks of Anakeesta Formation exposed along roadcuts, in debris flow deposits, or in rock piles at construction sites. Aluminum-rich "white slime" was only observed at Beech Flats ( $\mathrm{pH}$ 5.8) as a thin coating on streambed rocks. Poorly crystalline, relatively insoluble aluminum hydroxysulfate minerals (basaluminite, hydrobasaluminite)

typically form where acid rock drainage mixes with neutral water or reacts with carbonate so that $\mathrm{pH}$ increases to about 5.0 or higher (Bigham and Nordstrom 2000). White slimes were also observed as thin coating on top of red slimes in pools below both the Anakeesta Ridge and Road Prong debris flows, but it was not possible to sample these as discrete phases for chemical analysis. In both cases, stream $\mathrm{pH}$ was $>6$. These white coatings may represent changes in water $\mathrm{pH}$ over time, such that the underlying red slimes precipitated during periods of lower $\mathrm{pH}$. Modally abundant muscovite, chlorite, and feldspars provide the bedrock source of the aluminum; muscovite comprises $35 \mathrm{vol} \%$ or more of pyritic Anakeesta Formation in the park (Hadley and Goldsmith 1963).

Geochemical data for the ochres that lack a significant detrital component (Table 2) and for which water chemistry data are available are summarized in Table 7, along with data for ochres from other studies. Trace element partitioning between ochres and their associated waters can be examined by computing concentration factors in the form of distribution coefficients $(\mathrm{Kd})$ : $\mathrm{Kd}=($ element concentration in ochre $) /($ element concentration in water) where concentrations are expressed in $\mathrm{mg} / \mathrm{kg}$ ( $\mathrm{mg} / \mathrm{kg}$ for ochres; $\mathrm{mg} / \mathrm{L}$ for waters). The net surface charge of ideal nanophase hydrous ferric oxide minerals (ferrihydrite) is positive at low $\mathrm{pH}$, passes through a zero point charge (zpc), and becomes negative with increasing $\mathrm{pH}$; the percent of a particular element sorbed follows a sigmoidal curve that passes through the zpc (Parks 1965; Stumm 1992; Bigham and Nordstrom 2000). Ion binding to hydrous ferric oxides (from 0 to $100 \%$ bound) occurs over a narrow range of 1 to $2 \mathrm{pH}$ units. For cations, the curve has a positive slope such that binding occurs at the high $\mathrm{pH}$ end of the curve (Fig. 13a). For anions, the opposite occurs. Dzombak and Morel (1990) showed that the sorption edge for zinc to bind to ferrihydrite lies at a higher $\mathrm{pH}$ (5 to 7) compared to the sorption edges for copper (4 to 6) and lead (3 to 5). Thus, zinc is typically difficult to remove from acid drainage. Similarly, the critical $\mathrm{pH}$ range for manganese is 6.5 to 7.5 (Kinniburgh and Jackson 1981).

In natural systems, the ochre phases that comprise bottom sediments or rock coatings are complex and the ochre minerals are all metastable with respect to goethite. 
Table 7

Comparison of ochres in underground mine workings and weathered Anakeesta Formation in the Smokies with acid-mine drainage ochres from metal and coal mining areas

\begin{tabular}{|c|c|c|c|c|c|c|}
\hline & & $\begin{array}{l}\text { Mine areas } \\
\text { (This study) } \\
n=4\end{array}$ & $\begin{array}{c}\text { Anakeesta Fm } \\
\text { (This study) } \\
n=4\end{array}$ & $\begin{array}{l}\text { St. Kevin Gulch,CO } \\
\text { (Smith and others 1991) } \\
n=6\end{array}$ & $\begin{array}{c}\text { Welsh metal mines } \\
\text { (Fuge and others 1994) } \\
n=6\end{array}$ & $\begin{array}{l}\text { Ohio coal mines } \\
\text { (Winland and others 1991) } \\
n=28\end{array}$ \\
\hline $\mathrm{pH}_{\text {water }}$ & - & $3.0-6.4$ & $4.1-6.4$ & $3.3-4.0$ & $2.3-5.0$ & $2.6-7.8$ \\
\hline $\mathrm{Al}$ & $\%$ & $0.03-2.7$ & $0.54-1.4$ & $0.3-5.0$ & $0.04-1.4$ & 3 \\
\hline $\mathrm{Fe}$ & $\%$ & $23-50$ & $24-44$ & $16-43$ & $13-41$ & $48.6(35.7)$ \\
\hline$S$ & $\%$ & $4.4,5.2$ & $0.5,0.8$ & $0.6-3.6$ & - & $(3.2)$ \\
\hline $\mathrm{C}$ & $\%$ & $0.32,0.14$ & 1.9 & $3.2-8.8$ & - & $0.7-5.3$ \\
\hline As & $\mathrm{mg} / \mathrm{kg}$ & $<10$ & $2-50$ & $40-72$ & $13-1,510$ & 1,296 \\
\hline $\mathrm{Cu}$ & $\mathrm{mg} / \mathrm{kg}$ & $430-12,900$ & 20 & $56-201$ & $44-1,910$ & 53 \\
\hline $\mathrm{Mn}$ & $\mathrm{mg} / \mathrm{kg}$ & $<4-16,600$ & $17-3,800$ & $97-436$ & $13-688$ & 450 \\
\hline $\mathrm{Pb}$ & $\mathrm{mg} / \mathrm{kg}$ & $46-443$ & $1-14$ & $106-560$ & $127-80,300$ & - \\
\hline $\mathrm{Zn}$ & $\mathrm{mg} / \mathrm{kg}$ & $56-1,020$ & $10-430$ & $167-2,480$ & $246-24,600$ & 163 \\
\hline
\end{tabular}

${ }^{a}$ Ohio coal mine data are mean values for acid-soluble fractions; values in parentheses are for the total sediment, including detrital material that comprises 2 to $67 \mathrm{wt} \%$ of the samples

a
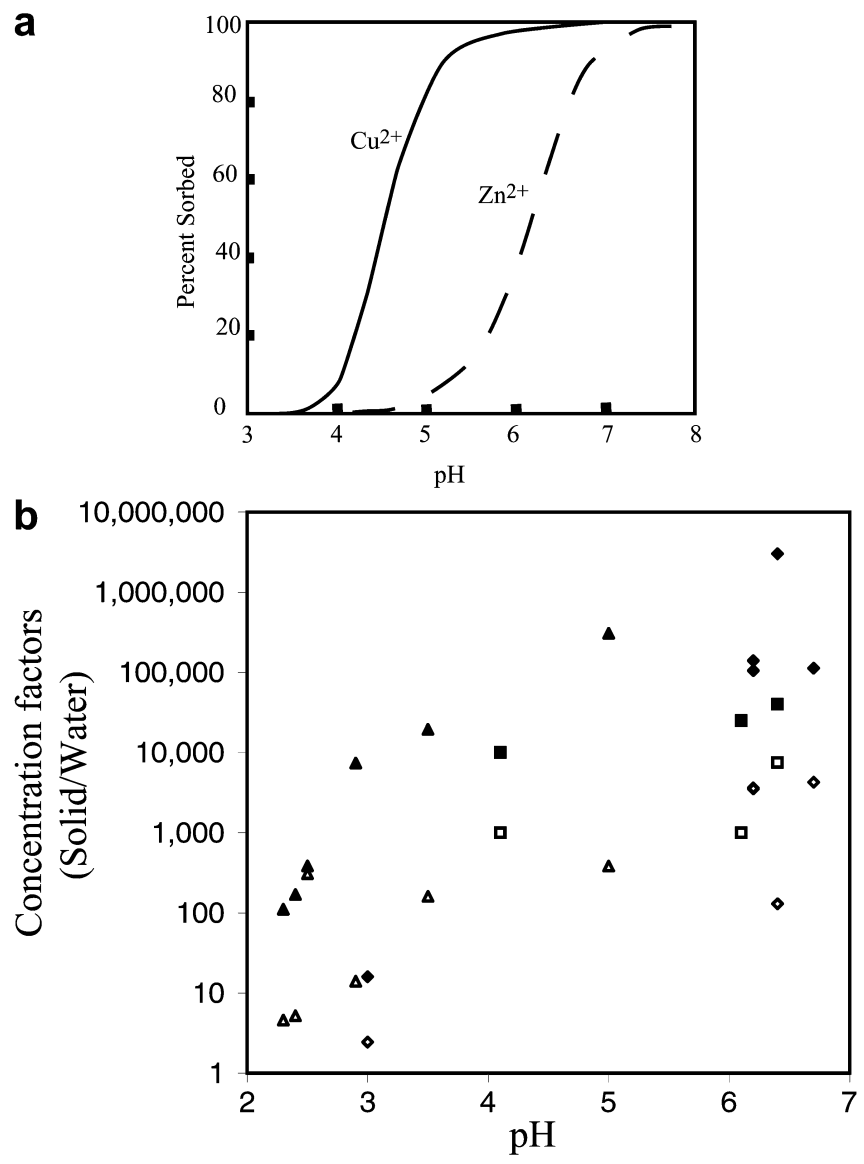

Fig. 13

Sorption of metals on ochre.a Model curves for binding of metal ion on ferrihydrite (from Dzombak and Morel 1990). Note the narrow $\mathrm{pH}$ range over which sorption occurs and the higher $\mathrm{pH}$ range for sorption of zinc relative to copper. $\mathbf{b}$ Concentration factors (Kd) for trace element distributions between ochres and associated waters as a function of water $\mathrm{pH}$. Filled symbols, copper. Open symbols, zinc.Diamonds, underground mine ochre samples from the Fontana and Hazel Creek mines (Table 2). Squares, ochres in streams below debris flows and at a groundwater seep in Anakeesta Formation (Table 2). Triangles, ochres associated with acid-mine drainage in Wales (Fuge and others 1994)
Webster and others (1998) showed that sorption edges for copper, lead, zinc, and cadmium shift to lower $\mathrm{pH}$ for natural, goethite-rich mine-drainage precipitate. In ochres at the Levant mine ( $\mathrm{Sn}, \mathrm{Cu}, \mathrm{As}$ ) in Cornwall, Bowell and Bruce (1995) showed that the total trace metal content of the complex ochres (goethite, ferrihydrite, lepidocrocite, jarosite, and other minerals) was highest at higher $\mathrm{pH}$; anions (As, Sb, Mo) sorbed to ochres more strongly at low $\mathrm{pH}(<5)$, whereas base metal sorbed to a greater extent at higher $\mathrm{pH}$ (5 to 8 ).

Concentration factors for copper and zinc for detrital-poor ochres from our study are plotted in Fig. 13b along with the data of Fuge and others (1994) for ochres from Wales (Table 7). Trends of increasing concentration of copper and zinc in the solid ochre phase with increasing $\mathrm{pH}$ are in agreement with predicted trends for sorption on hydrous ferric oxides (Fig. 13a). For a given $\mathrm{pH}$, concentration factors for copper are an order of magnitude higher than for zinc. Ochres associated with natural acid drainage generated by oxidative weathering of sulfide minerals in Anakeesta Formation fall along the same trends as ochres associated with metal mines. Thus, the process is similar and ochres that develop downstream of debris flows likely play a key role in the process of self-mitigation of affected streams over time.

\section{Conclusions}

Removal of mine waste at the time of mine closure, flooding of underground workings, and the wet climate of the Great Smoky Mountains contribute to the lack of significant acid-mine drainage formed from a type of mineral deposit that tends to develop acid-mine drainage elsewhere. However, stream sediments immediately downstream of mine workings maintain metal concentrations that exceed stream sediment quality guidelines for aquatic ecosystems some 50 years after mining ceased. Oxidative weathering of sulfide minerals disseminated throughout the shale (1) contributes sediments that in some areas, 
exceed threshold stream sediment quality guidelines for aquatic ecosystems for base metals, and, locally, exceed probable effects concentrations for arsenic, an element not derived from the metal mines, (2) leads to precipitation of secondary minerals which sequester metals and acidity, and (3) develops acid-rock drainage in streams that drain areas where human activities or natural storm events that form debris flows cause intermittent exposure of fresh sulfidic rock surfaces to air and water.

Weathering of exposed bedrock results in secondary mineral formation. Secondary mineral formation and dissolution is an important process in cycling metals and acidity back and forth between solids and solutions in surface environments. In areas where surficial materials include metal-sulfide minerals, such as Great Smoky Mountains National Park, weathering can produce positive and negative impacts on ecosystems via sequestration and release of metals and acidity.

Acknowledgements The authors thank the National Park Service for permission to sample within Great Smoky Mountains National Park and for support of this study, especially Carroll Schell. Rick Verner and Dale Raxter of the National Park Service greatly facilitated field work. USGS colleagues Art Schultz, Scott Southworth, and Geoff Plumlee, and Professor Don Byerly of the University if Tennessee pointed out key locations and provided background information. Dave Haffner, John Wormington, Peggie Wormington, and Ryan Barden assisted in the field and laboratory. This paper benefited from peer reviews by USGS colleagues Scott Southworth and Bill Cannon.

\section{References}

Abernathy AR, Larson GL, Mathews RC Jr (1984) Heavy metals in the surficial sediments of Fontana Lake, North Carolina. Water Res 18:351-354

Alpers CN, Blowes DW, Nordstrom DK, Jambor JL (1994) Secondary minerals and acid mine-water chemistry. In: Jambor JL, Blowes DW (eds) The environmental geochemistry of sulfide mine-wastes. Mineralogical Association of Canada, Short Course Handbook, vol 22, pp 247-270

Bacon JR, Maas RP (1979) Contamination of Great Smoky Mountains trout streams by exposed Anakeesta Formation. J Environ Qual 8:538-543

Bigham JM, Nordstrom DK (2000) Iron and aluminum hydroxysulfates from acid sulfate waters. In: Alpers $\mathrm{CN}$, Jambor JL, Nordstrom, DK (eds) Sulfate minerals -crystallography, geochemistry, and environmental significance. Reviews in Mineralogy, vol 40, pp 351-403

Bowell RJ, Bruce I (1995) Geochemistry of iron ochres and mine waters from Levant mine, Cornwall. Appl Geochem 10(2):237250

Byerly DW (1994) Characterization of rocks for the proposed Ocoee Olympic Whitewater Venue, Polk County, Tennessee. Report of Investigation. In: USDA Forest Service Final EIS, 1996 Olympic whitewater slalom venue, Ocoee River, Polk Co, TN, Ocoee Ranger District, Cherokee National Forest, Management Bull R8-MB 68-A, pp G-5-1-G-5-10

Byerly DW (1996) Handling acid-producing material during construction. Environ Eng Geosci II(1): 49-57

Chou IM, Seal RR II, Hemingway BS (2002) Determination of melanterite-rozenite and chalcanthite-bonatitte equilibria by humidity measurements at 0.1 MPa. Am Mineral 87:108-114
Coskren TD, Lauf RJ (1996) Secondary sulfates of Alum Cave Bluff, Great Smoky Mountains, Tennessee. Rocks and Minerals 71(3):192-193

Coskren TD, Lauf RJ (2000) The minerals of Alum Cave Bluff, Great Smoky Mountains, Tennessee. Mineral Rec 31:163-175

Crock JG, Lichte FE, Briggs PH (1983) Determination of elements in National Bureau of Standards' geological reference materials SRM 278 obsidian and SRM 688 basalt by inductively coupled argon plasma-atomic emission spectrometry. Geostand Newsl 7:335-340

Dagenhart TV Jr (1980) The acid mine drainage of Contrary Creek, Louisa County, Virginia - factors causing variations in stream water chemistry. MS Thesis, Univeristy of Virginia

Di Toro DM, Mahoney JD, Hansen DJ, Scott KJ, Hicks JB, Mays SM, Redmond MS (1990) Toxicity of cadmium in sediments the role of acid-volatile sulfide. Environ Toxicol Chem 9:14871502

Dzombak DA, Morel FMM (1990) Surface complexation modeling: hydrous ferric oxide. Wiley, New York

Espenshade GH (1963) Geology of some copper deposits in North Carolina, Virginia, and Alabama. USGS Bulletin 1142-I

Feiss GP, Maybin AH III, Riggs SR, Grosz AE (1991) Mineral resources of the Carolinas. In: Horton JW Jr, Zullo VA (eds) The geology of the Carolinas. Carolina Geol Soc 50th Anniv Vol, pp 319-345

Flohr MJK, Hammarstrom JM (1997) Formation of gossan and oxidation of sulfide ores as analogs of oxidation of tailings piles (Abstr). USGS Open-File Report 97-496:24

Flohr MJK, Dillenburg RG, Plumlee GS (1995) Characterization of secondary minerals formed as a result of weathering of Anakeesta Formation, Alum Cave, Great Smoky Mountains National Park, Tennessee. USGS Open-File Report 95-477

Flum T, Nodvin SC (1995) Factors affecting streamwater chemistries in the Great Smoky Mountains, USA. Water Air Soil Pollut 85:1707-1712

Flum T, Shubzda J, Rhodes H (1997) Preliminary assessment of water quality in the Great Smoky Mountains National Park. Report prepared for the National Park Service, Great Smoky Mountains National Park

Foley N, Southworth S, Schultz AP, Ayuso RA, Robinson GR, Seal RR (2001) Geochemical, mineralogical, and environmental characteristics of metamorphosed black shales of the Central Appalachians, with comparisons to metalliferous shales of the Northern Appalachians. USGS Open-File Report 01-406:

111-114

Fortescue JAC (1992) Landscape geochemistry: retrospect and prospect -1990. Appl Geochem 7:1-53

Fuge R, Pearce FM, Pearce NJG, Perkins WT (1994) Acid mine drainage in Wales and influence of ochre precipitation on water chemistry. In: Alpers CA, Blowes DW (eds) Environmental geochemistry of sulfide oxidation. ACS Symposium Series 550, pp 261-274

Hadley JB, Goldsmith R (1963) Geology of the eastern Great Smoky Mountains, North Carolina and Tennessee. USGS Prof Paper 349-B

Hageman PL, Briggs PH (2000) A simple field leach test for rapid screening and qualitative characterization of mine waste dump material on abandoned mine lands: In: ICARD 2000, Proc Fifth Int Conf on Acid Rock Drainage, vol II, pp 1463-1475

Hammarstrom JM, Seal RR II, Meier AL, Kornfeld JM (2000) Secondary sulfate minerals associated with acid drainage in the eastern U.S. Recycling of metal and acidity in surficial environments. Geol Soc Am Abstr Programs 32:A180

Herrmann R, Morgan EL, Green RL (1979) Aluminum precipitation, Beech Flats and Walker's Prong Creeks, Great Smoky Mountains National Park. In: Lin RL (ed) Conference on Scientific Research in the National Parks, Vol II. Nat Park Service Trans and Proc Ser 5, pp 715-718 
Huckabee JW, Goodyear CP, Jones RD (1975) Acid rock in the Great Smokies: unanticipated impact of aquatic biota of road construction in regions of sulphide mineralization. Trans Am Fish Soc 104(4):677-684

Jambor JL, Nordstrom DK, Alpers CN (2000) Metal-sulfates salts from sulfide mineral oxidation. In: Alpers CN, Jambor JL, Nordstrom, DK (eds) Sulfate minerals - crystallography, geochemistry, and environmental significance. Reviews in Mineralogy, vol 40, pp 303-350

King PB (1964) Geology of the central Great Smoky Mountains, Tennessee. USGS Prof Paper 349-C

King PB, Neuman RB, Hadley JB (1968) Geology of the Great Smoky Mountains National Park, Tennessee and North Carolina. USGS Prof Paper 587

Kinniburgh DG, Jackson ML (1981) Cation adsorption by hydrous metal oxides and clay. In: Anderson MA, Rubin AJ (eds) Adsorption of inorganics at solid-liquid interfaces. Ann Arbor Science, Ann Arbor, MI, pp 91-160

Krauskopf KB (1979) Introduction to geochemistry, 2nd edn. McGraw-Hill, New York

Kucken DJ, Davis JS, Petranka JW, Smith CK (1994) Anakeesta stream acidification and metal contamination: effects on a salamander community. J Environ Qual 23:1311-1317

Lauf RJ (1997) Secondary sulfate minerals from Alum Cave Bluff: microscopy and microanalysis. Oak Ridge National Laboratory ORNL/TM-13471

Lawrence RW, Wang Y (1997) Determination of neutralization potential in the prediction of acid rock drainage. In: Proc 4th Int Conf Acid Rock Drainage, Vancouver, BC. Society for Mining, Metallurgy, and Exploration, Littleton, CO, pp 449-464

Lesure FG, Force ER, Windolph JF, Hill JJ (1977) Mineral resources of the Joyce Kilmer-Slickrock Wilderness, North Carolina-Tennessee. USGS Bulletin 1416

Lichte FE, Meier AL, Crock JG (1987) Determination of rare earth elements in geological materials by inductively coupled plasma mass spectrometry. Anal Chem 59(8):1150-1157

MacDonald DD, Ingersoll CG, Berger TA (2000) Development and evaluation of consensus-based sediment quality guidelines for freshwater ecosystems. Arch Environ Contam Toxicol 39:20-31 Mathews RC Jr, Morgan EL (1982) Toxicity of Anakeesta Formation leachates to shovel-nosed salamander, Great Smoky Mountains National Park. J Environ Qual 11:102-106

Meier AL (1980) Flameless atomic absorption determination of gold in geological materials. J Geochem Explor 13:75-85

Meier AL, Grimes DJ, Ficklin WH (1994) Inductively coupled plasma mass spectrometry - a powerful analytical tool for mineral resource and environmental studies. USGS Circ 1103-A:67-68

O’Leary RM, Hageman PL, Crock JG (1996) Mercury in water, geologic, and plant materials by continuous flow-cold vaporatomic absorption spectrometry. In: Arbogast BF (ed) Analytical methods manual for the Mineral Resource Surveys Program, US Geological Survey. USGS Open-File Report 96-525, pp 42-50

Parks GA (1965) The isoelectric points of solid oxides, solid hydroxides, and aqueous hydro complex systems. Chem Rev 65:177-198

Peacor DR, Rouse RC, Essene EJ (1999a) Coskrenite$(\mathrm{Ce}),(\mathrm{Ce}, \mathrm{Nd}, \mathrm{La})_{2}\left(\mathrm{SO}_{4}\right)_{2}\left(\mathrm{C}_{2} \mathrm{O}_{4}\right) \cdot 8 \mathrm{H}_{2} \mathrm{O}$, a new rare-earth oxalate mineral from Alum Cave Bluff, Tennessee: characterization and crystal structure. Can Mineral 37:1453-1462

Peacor DR, Rouse RC, Coskren TD, Essene EJ (1999b) Destinezite ("diadochite"), $\mathrm{Fe}_{2}\left(\mathrm{PO}_{4}\right)\left(\mathrm{SO}_{4}\right)(\mathrm{OH}) \cdot 6 \mathrm{H}_{2} \mathrm{O}$ : its crystal structure and role as a soil mineral at Alum Cave Bluff, Tennessee. Clays Clay Miner 47(1):1-11

Pitard FF (1993) Pierre Gy's sampling theory and sampling practice - heterogeneity, sampling correctness, and statistical process control, 2nd edn. CRC Press, Boca Raton

Robinson GR, Lesure FG, Marlowe JI, Foley NK, Clark SH (1992) Bedrock geology and mineral resources of the Knoxville $1^{\circ} \times 2^{\circ}$ quadrangle, Tennessee, North Carolina, and South Carolina. USGS Bulletin 1979

Rouse RC, Peacor DR, Coskren TD, Essene EJ, Lauf RJ (2001) The new minerals levinsonite- $(\mathrm{Y})\left[(\mathrm{Y}, \mathrm{Nd}, \mathrm{Ce}) \mathrm{Al}\left(\mathrm{SO}_{4}\right)_{2}\left(\mathrm{C}_{2} \mathrm{O}_{4}\right) \cdot 12 \mathrm{H}_{2} \mathrm{O}\right]$ and zugshunstite- $(\mathrm{Ce})\left[(\mathrm{Ce}, \mathrm{Nd}, \mathrm{La}) \mathrm{Al}\left(\mathrm{SO}_{4}\right)_{2}\left(\mathrm{C}_{2} \mathrm{O}_{4}\right) \cdot 12 \mathrm{H}_{2} \mathrm{O}\right]$ : coexisting oxalates with different structures exhibiting strong differentiation of LREE and HREE. Geochim Cosmochim Acta 65(7):1101-1115

Schaeffer MF, Clawson PA (1996) Identification and treatment of potential acid-producing rocks and water quality monitoring along a transmission line in the Blue Ridge Province, southwestern North Carolina. Environ Eng Geosci 2:35-48

Schultz AP (1998) Geologic map of the Mount LeConte 7.5 minute quadrangle, Great Smoky Mountains National Park, Tennessee and North Carolina. USGS Open-File Report 98-32

Seal RR II, Hammarstrom JM, Southworth CS, Meier AL, Haffner DP, Schultz AP, Plumlee GS, Flohr MJK, Jackson JC, Smith SM, Hageman PL (1998) Preliminary report on water quality associated with the abandoned Fontana and Hazel Creek mines, Great Smoky Mountains National Park, North Carolina and Tennessee. USGS Open-File Report 98-476

Seal RR II, Schultz AP, Haffner DP, Meier AL (1999) Water quality and inorganic chemistry of Icewater Spring and Mount Le Conte Spring, Great Smoky Mountains National Park, Tennessee and North Carolina. USGS Open-File Report 99-375

Seal RR II, Hammarstrom JM, Foley NK, Alpers CN (2000) Geoenvironmental models for seafloor base- and precious-metal massive sulfide deposits. In: ICARD 2000, Proc 5th Int Conf Acid Rock Drainage, Society for Mining, Metallurgy, and Exploration, Littleton, CO, Vol II, pp 151-160

Seal RR II, Hammarstrom JM, Foley NK, Alpers CN (2002) Geoenvironmental models for seafloor massive sulfide deposits. In: Seal RR II, Foley NK (eds) Progress on geoenvironmental models for selected deposit types. USGS Open-File Report 02-195. http://pubs.usgs.gov/of/2002/of02-195/

Shacklette HT, Boerngen JG (1984) Element concentrations in soils and other surficial materials of the conterminous United States. USGS Prof Paper 1270

Silsbee DG, Larson GL (1982) Water quality of streams in Great Smoky Mountains National Park. Hydrobiologia 89:97-115

Smith KS, Ranville JF, Macaldy DL (1991) Predictive modeling of copper, cadmium, and zinc partitioning between streamwater and bed sediment from a stream receiving acid mine drainage, St. Kevin Gulch, Colorado. USGS Water-Resources Invest Rep 91-4034:380-386

Smith KS, Ramsey CA, Hageman PL (2000) Sampling strategy for the rapid screening of mine-waste dumps on abandoned mine lands. In: ICARD 2000, Proc 5th Int Conf Acid Rock Drainage, Society for Mining, Metallurgy, and Exploration, Littleton, CO, Vol I, pp 1453-1461

Southworth S (1995) Preliminary geologic map of the Great Smoky Mountains National Park within the Fontana Dam and Tuskegee quadrangles, Swain County, North Carolina. USGS Open-File Report 95-264

Southworth S, Schultz A, Naeser C, Naesar N, Chirco P, Matmon A, Bierman P, Pavich M (2001) Using geology to understand flora, fauna and the evolution of the Great Smoky Mountain region. USGS Open-File Report 01-046:53-54

Stumm W (1992) Chemistry of the solid-water interface: processes at the mineral-water and the particle-water interface in natural systems. Wiley, New York

Tingle AR (1995) A geochemical assessment of highway construction through sulfidic rocks. MS Thesis, University of Tennessee, Knoxville

Trumpf WF, Morgan EL, Herrmann R (1979) Man induced acid drainage impact on benthic macroinvertebrate communities in the Great Smoky Mountains National Park. In: Lin RL (ed) 
Conference on Scientific Research in the National Parks, Vol I. Nat Park Service Trans and Proc Ser 5, pp 643-647

US EPA (1997) The incidence and severity of sediment contamination in surface waters of the United States. Volume 1: National stream sediment survey.

EPA-823-R-97-006

US EPA (2000) Region 9 Preliminary remediation goals. http://www.epa.gov/region09/waste/sfund/prg/index.htm

Van Gosen BS, Eppinger RG, Hammarstrom JM, Briggs PH, Crock JG, Gent C, Meier AL, Sutley SJ, Theodorakos PM (2000) Analytical data for reconnaissance geochemical samples from mine dumps, stream sediments, and waters at the Thompson Creek Tungsten Mine, Custer County, Idaho. USGS Open-File
Report 00-0239. http://greenwood.cr.usgs.gov/pub/open-filereports/ofr-00-0239/

Walsh GE, Nimmo DR (1992) Chemical and toxicological analyses of water and sediment near abandoned mine seepage entering Sugar Fork and Eagle Creek, Great Smoky Mountains National Park: Internal National Park Service Water Resources Division Report

Webster JG, Swedlund PJ, Webster KS (1998) Trace metal adsorption onto an acid mine drainage (III) oxy-hydroxy sulfate. Environ Sci Tech 32:1361-1368

Winland RL, Traina SJ, Bigham JM (1991) Chemical composition of ochreous precipitates from Ohio coal mine drainage. J Environ Qual 20:452-460 
Table ESM 1. Sample key and associated water data for ochres.

\begin{tabular}{|c|c|c|c|c|c|c|}
\hline Key & Sample & Locality & Description & Water sample & $\mathrm{pH}$ & $\begin{array}{l}\text { Specific } \\
\text { conductance } \\
(\mu \mathrm{S} / \mathrm{cm})\end{array}$ \\
\hline \multicolumn{7}{|c|}{ Ochres associated with weathered Anakeesta Formation and debris flows } \\
\hline 1 & RTN4-HP & Road-to-Nowhere & $\begin{array}{l}\text { Protohardpan ochre mud in a groundwater seep on a } \\
\text { roadcut in Anakeesta Formation. }\end{array}$ & RTN-4-3 & 4.1 & 122 \\
\hline 2 & ANRS-3 & $\begin{array}{l}\text { Anakeesta Ridge debris } \\
\text { flow }\end{array}$ & $\begin{array}{l}\text { Rusty coating on breakaway surface of rock wedge } \\
\text { failure. No water at the site. }\end{array}$ & None & - & - \\
\hline 3 & ANRS-4A & $\begin{array}{l}\text { Anakeesta Ridge debris } \\
\text { flow }\end{array}$ & $\begin{array}{l}\text { White slime precipitate in ponded surface water runoff } \\
\text { from the flow area. }\end{array}$ & ANRS-1-3 & 6.1 & 30 \\
\hline 4 & ANRS-4B & $\begin{array}{l}\text { Anakeesta Ridge debris } \\
\text { flow }\end{array}$ & $\begin{array}{l}\text { Red slime precipitate underlying white slime (ANRS- } \\
\text { 4A). }\end{array}$ & ANRS-1-3 & 6.1 & 30 \\
\hline 5 & $\mathrm{RP}-2 \mathrm{c}$ & Road Prong & $\begin{array}{l}\text { Yellowboy precipitate in Road Prong stream } 10 \mathrm{~m} \\
\text { from point where stream exits the } 1996 \text { debris flow. } \\
\text { Bulk sample. Note that white slime forms a thin layer } \\
\text { on top of red slime. }\end{array}$ & RPSL-3-3 & 6.4 & 15 \\
\hline 6 & $\mathrm{RP}-3$ & Road Prong & $\begin{array}{l}\text { Streambed precipitate } \sim 0.1 \mathrm{~km} \text { downstream from RP- } \\
2 \mathrm{c} \text {. Much less precipitate present on streambed here. } \\
\text { Mainly see coatings on streambed rocks; coatings die } \\
\text { out downstream. }\end{array}$ & None & - & - \\
\hline \multicolumn{7}{|c|}{ Hardpans, ochreous muds, and stalactites associated with abandoned copper mines } \\
\hline 7 & 98FM-HP1 & Fontana mine & $\begin{array}{l}\text { Protohardpan developed on phyllite in streambed at } \\
\text { confluence of a groundwater seep and creek. }\end{array}$ & None & - & - \\
\hline 8 & 98FM-HP2 & Fontana mine & $\begin{array}{l}\text { Protohardpan crust at point of groundwater discharge } \\
\text { from the mine area into Fontana Lake. }\end{array}$ & None & - & - \\
\hline 9 & 98JHFM-HP3 & Fontana mine & $\begin{array}{l}\text { Underground sample of dripstone terrace formed along } \\
\text { adit wall. }\end{array}$ & FM-6-2 & 3.0 & 1,112 \\
\hline 10 & FM-10-2B & Fontana mine & Hardpan in stream below west seep. & FM-10-2 & 6.7 & 64 \\
\hline 11 & FM-9-2A & Fontana mine & $\begin{array}{l}\text { Ochre mud from floor of pool at surface seep } \\
\text { downgradient of mine entrance. }\end{array}$ & FM-9-2 & 6.2 & 63 \\
\hline 12 & FM-9-2C & Fontana mine & $\begin{array}{l}\text { Orange ochre mud in iron bog }(>45 \mathrm{~cm} \text { thick) } \\
\text { downgradient of seep pool (FM-9-2A). }\end{array}$ & None & - & - \\
\hline
\end{tabular}


main adit ceiling. Water sample collected from adit

floor below the stalactite.

14 HCM-STAL Hazel Creek mine

Underground sample of stalactite knob;drip water

HCM-6-2

6.4 
Table ESM 2. Stream sediment sample locations.

\begin{tabular}{|c|c|c|c|c|c|c|c|c|}
\hline Locality & Sample No. & 7.5' Quadrangle & Latitude & Longitude & Date sampled & Description & Pyrite & \%Fines \\
\hline Alum Cave Trail area & ACT-SS-97 & Mount Le Conte & $35^{\circ} 38^{\prime} 36^{\prime \prime}$ & $83^{\circ} 26^{\prime} 28^{\prime \prime}$ & 22-Jun-97 & $\begin{array}{l}\text { Small stream that crosses Alum Cave Trail at an elevation of } \\
\text { about } 1,402 \mathrm{~m} \text { below Alum Cave }\end{array}$ & $X$ & 10 \\
\hline Alum Cave Trail area & 98ACT2-SS & Mount Le Conte & $35^{\circ} 38^{\prime} 36^{\prime \prime}$ & $83^{\circ} 26^{\prime} 28^{\prime \prime}$ & 12-Sep-98 & $\begin{array}{l}\text { Small stream that crosses Alum Cave Trail at an elevation of } \\
\text { about } 1,402 \mathrm{~m} \text { below Alum Cave; replicate (1998) for sample } \\
\text { ACT-SS-9. }\end{array}$ & & n.d. \\
\hline Alum Cave Trail area & STYX-SS & Mount Le Conte & $35^{\circ} 38^{\prime} 26^{\prime \prime}$ & $83^{\circ} 26^{\prime} 1.6^{\prime \prime}$ & 22-Jun-97 & Styx Branch at footbridge on Alum Cave Trail & $x$ & 2 \\
\hline Alum Cave Trail area & HHS-R1-2-SS & Mount Le Conte & $35^{\circ} 38^{\prime} 20^{\prime \prime}$ & $83^{\circ} 26^{\prime} 17^{\prime \prime}$ & 22-Jun-97 & $\begin{array}{l}\text { Huggins Hell Slide approximately } 30 \mathrm{~m} \text { west of footbridge to } \\
\text { Arch Rock; sediment from the bottom of a pool formed by } \\
\text { seepage from the debris flow. }\end{array}$ & & 6 \\
\hline Alum Cave Trail area & NPS-75-SS & Mount Le Conte & $35^{\circ} 37^{\prime} 47.5^{\prime \prime}$ & $83^{\circ} 26^{\prime} 57.5^{\prime \prime}$ & 23-Jun-97 & $\begin{array}{l}\text { Alum Cave Creek at bridge on Alum Cave Trail at elevation } \\
1164 \mathrm{~m} ; 50 \mathrm{~m} \text { from sample site NPS } 74 .\end{array}$ & & 5 \\
\hline Walker Camp Prong & NPS-74-SS & Mount Le Conte & $35^{\circ} 37^{\prime} 45.2^{\prime \prime}$ & $83^{\circ} 27^{\prime} 1.7^{\prime \prime}$ & 23-Jun-97 & $\begin{array}{l}\text { Walker Camp Prong bridge on Alum Cave Trail just above } \\
\text { the confluence of Alum Cave Creek with Walker Camp Prong }\end{array}$ & & 4 \\
\hline Walker Camp Prong & NPS-237-SS1 & Mount Le Conte & $35^{\circ} 37^{\prime} 29.3^{\prime \prime}$ & $83^{\circ} 25^{\prime} 1^{\prime \prime}$ & 23-Jun-97 & Walker Camp Prong bridge on U.S. 441 at elevation $1,375 \mathrm{~m}$ & $x$ & 2 \\
\hline Walker Camp Prong & NPS-237-SS2 & Mount Le Conte & $35^{\circ} 37^{\prime} 29.3^{\prime \prime}$ & $83^{\circ} 25^{\prime} 1^{\prime \prime}$ & 23-Jun-97 & $\begin{array}{l}\text { Walker Camp Prong bridge on U.S. } 441 \text { at elevation 1,375 m; } \\
\text { replicate sample for quality control }\end{array}$ & & 1 \\
\hline Beech Flats & BCFT-1-3-SS & Clingmans Dome & $35^{\circ} 36^{\prime} 27.7^{\prime \prime}$ & $83^{\circ} 26^{\prime} 14.0^{\prime \prime}$ & 14-Sep-98 & $\begin{array}{l}\text { Beech Flats Prong upstream site from highway fill dump; no } \\
\text { precipitates on streambed. Trumpf and others ( } 1979) \\
\text { reported water data for this site for the period July } 1975 \\
\text { through June } 1976 \text { as site } 1 .\end{array}$ & & n.d. \\
\hline Beech Flats & BCFT-2-3-SS & Clingmans Dome & $35^{\circ} 36^{\prime} 24.8^{\prime \prime}$ & $83^{\circ} 26^{\prime} 4.9^{\prime \prime}$ & 14-Sep-98 & $\begin{array}{l}\text { Beech Flats Prong below highway fill; streambed coated with } \\
\text { white precipitate. Trumpf and others (1979) reported water } \\
\text { data for this site for the period July } 1975 \text { through June } 1976 \\
\text { as site } 2 \text { and documented reductions in density of benthic } \\
\text { macroinvertebrates downstream from this site. }\end{array}$ & & n.d. \\
\hline Beech Flats & BCFT-5-3-SS & Clingmans Dome & $35^{\circ} 36^{\prime} 8.9^{\prime \prime}$ & $83^{\circ} 24^{\prime} 57.4^{\prime \prime}$ & 14-Sep-98 & $\begin{array}{l}\text { Beech Flats Prong at horseshoe bend in U.S. } 44,1.8 \mathrm{~km} \\
\text { downstream from BCFT-2-3-SS }\end{array}$ & & n.d. \\
\hline $\begin{array}{l}\text { Chimneys Picnic Area } \\
\text { (NPS site) }\end{array}$ & NPS-66-SS & Mount Le Conte & $35^{\circ} 38^{\prime} 18^{\prime \prime}$ & $83^{\circ} 29^{\prime} 12^{\prime \prime}$ & 23-Jun-97 & $\begin{array}{l}\text { West Prong Little Pigeon River at footbridge near Chimneys } \\
\text { picnic area at elevation } 817 \mathrm{~m}\end{array}$ & & 3 \\
\hline Road Prong & RP-1-SS & Clingmans Dome & $35^{\circ} 36^{\prime} 37.9^{\prime \prime}$ & $83^{\circ} 27^{\prime} 29.5^{\prime \prime}$ & 15-Sep-98 & Road Prong, upstream from 1996 debris flow & & n.d. \\
\hline Road Prong & RP-3-SS & Clingmans Dome & $35^{\circ} 36^{\prime} 38.2^{\prime \prime}$ & $83^{\circ} 27^{\prime} 40^{\prime \prime}$ & 15-Sep-98 & Road Prong, 10 m downstream from 1996 debris flow & & n.d. \\
\hline
\end{tabular}




\begin{tabular}{|c|c|c|c|c|c|c|c|c|}
\hline Locality & Sample No. & 7.5' Quadrangle & Latitude & Longitude & Date sampled & Description & Pyrite & \%Fines \\
\hline Road Prong & NPS-72-SS & Mount Le Conte & $35^{\circ} 37^{\prime} 59.8^{\prime \prime}$ & $83^{\circ} 28^{\prime} 11.4^{\prime \prime}$ & 23-Jun-97 & $\begin{array}{l}\text { Road Prong just above confluence of Road Prong and } \\
\text { Walker Camp Prong, below small falls. Site is approximately } \\
2 \text { km downstream from } 1996 \text { debris flow. }\end{array}$ & & 3 \\
\hline Road Prong & NPS-72-3-SS & Mount Le Conte & $35^{\circ} 37^{\prime} 59.8^{\prime \prime}$ & $83^{\circ} 28^{\prime} 11.4^{\prime \prime}$ & 14-Sep-98 & $\begin{array}{l}\text { Road Prong just above confluence of Road Prong and } \\
\text { Walker Camp Prong, below small falls. Site is approximately } \\
2 \text { km downstream from } 1996 \text { debris flow. Replicate for } \\
\text { sample NPS-72-SS }\end{array}$ & & 5 \\
\hline Road-to-Nowhere & RTN-3-3-SS & Bryson City & $35^{\circ} 27^{\prime} 18^{\prime \prime}$ & $83^{\circ} 28^{\prime} 58^{\prime \prime}$ & 09-Sep-98 & Peachtree Creek on north side of the Road-to-Nowhere. & & n.d. \\
\hline Cades Cove & CCAC-SS-97 & Cades Cove & $35^{\circ} 35^{\prime} 39^{\prime \prime}$ & $83^{\circ} 45^{\prime} 45.2^{\prime \prime}$ & 24-Jun-97 & $\begin{array}{l}\text { Anthony Creek, at footbridge above confluence with Maynard } \\
\text { Creek }\end{array}$ & & 6 \\
\hline Fontana copper mine & FM-97-1-SS & Fontana Dam & $35^{\circ} 28^{\prime} 41^{\prime \prime}$ & $83^{\circ} 45^{\prime} 58^{\prime \prime}$ & 17-Jun-97 & $\begin{array}{l}\text { Eagle Creek (small, intermittent stream that drains mine } \\
\text { workings and flows into the Eagle Creek arm of Fontana } \\
\text { Lake) above the uppermost mine workings. }\end{array}$ & $x$ & 13 \\
\hline Fontana copper mine & FM-97-2-SS & Fontana Dam & $35^{\circ} 28^{\prime} 39^{\prime \prime}$ & $83^{\circ} 45^{\prime} 58^{\prime \prime}$ & 17-Jun-97 & Eagle Creek below lowermost adit, upstream from seep & & 13 \\
\hline Fontana copper mine & FM-SS-97-3 & Fontana Dam & $35^{\circ} 28^{\prime} 39^{\prime \prime}$ & $83^{\circ} 45^{\prime} 58^{\prime \prime}$ & 17-Jun-97 & $\begin{array}{l}\text { Eagle Creek below seep, } 15 \mathrm{~m} \text { upstream from high water } \\
\text { mark; ochre floc noted }\end{array}$ & & 14 \\
\hline Fontana copper mine & FM-SS-97-4 & Fontana Dam & $35^{\circ} 28^{\prime} 39^{\prime \prime}$ & $83^{\circ} 45^{\prime} 58^{\prime \prime}$ & 17-Jun-97 & $\begin{array}{l}\text { Eagle Creek arm of Fontana Lake; bottom sediment } \\
\text { (sampled underwater) at the outlet of the intermittent stream } \\
\text { that drains the Fontana mine area }\end{array}$ & $x$ & 8 \\
\hline Fontana copper mine & FM-98-1-SS & Fontana Dam & $35^{\circ} 28^{\prime} 39^{\prime \prime}$ & $83^{\circ} 45^{\prime} 58^{\prime \prime}$ & 10-Sep-98 & $\begin{array}{l}\text { Eagle Creek (small, intermittent stream that drains mine } \\
\text { workings and flows into the Eagle Creek arm of Fontana } \\
\text { Lake) sampled downstream from mine adits }\end{array}$ & & n.d. \\
\hline Fontana copper mine & FM-98-2-SS & Fontana Dam & $35^{\circ} 28^{\prime} 29^{\prime \prime}$ & $83^{\circ} 45^{\prime} 58^{\prime \prime}$ & 10-Sep-98 & $\begin{array}{l}\text { Shore of Eagle Creek are of Fontana Lake at the outlet of the } \\
\text { intermittent stream that drains the Fontana mine; 30- } \\
\text { increment auger sample of } 20 \mathrm{~cm} \text { depth sediment layer. This } \\
\text { area was under water when visited in } 1997 .\end{array}$ & & n.d. \\
\hline Fontana copper mine & FM-98-3-SS & Fontana Dam & $35^{\circ} 28^{\prime} 29^{\prime \prime}$ & $83^{\circ} 45^{\prime} 58^{\prime \prime}$ & 10-Sep-98 & $\begin{array}{l}\text { Shore of Eagle Creek at stream that drains the Fontana mine; } \\
30 \text {-increment sample of top } 1 \mathrm{~cm} \text { of sediment. Same location } \\
\text { as FM-98-2-SS }\end{array}$ & & n.d. \\
\hline Fontana copper mine & FM-98-4-SS & Fontana Dam & $35^{\circ} 28^{\prime} 41^{\prime \prime}$ & $83^{\circ} 46^{\prime} 8^{\prime \prime}$ & 10-Sep-98 & $\begin{array}{l}\text { Ecoah Branch, east of the Fontana mine area for background } \\
\text { chemistry }\end{array}$ & & n.d. \\
\hline Hazel Creek copper mine & HCM-97-SS-1 & $\begin{array}{l}\text { Thunderhead } \\
\text { Mountain }\end{array}$ & $35^{\circ} 30^{\prime} 34^{\prime \prime}$ & $83^{\circ} 42^{\prime} 37^{\prime \prime}$ & 20-Jun-97 & Little Fork above Hazel Creek mine workings & & 9 \\
\hline Hazel Creek copper mine & HCM-97-SS-2 & $\begin{array}{l}\text { Thunderhead } \\
\text { Mountain }\end{array}$ & $35^{\circ} 30^{\prime} 25^{\prime \prime}$ & $83^{\circ} 42^{\prime} 34^{\prime \prime}$ & 20-Jun-97 & Little Fork below Hazel Creek mine dumps & & 13 \\
\hline
\end{tabular}


Locality

Sample No.

7.5' Quadrangle

Hazel Creek copper mine HCM-97-SS-3 Thunderhead Mountain

Latitude

Longitude

$35^{\circ} 30^{\prime} 21^{\prime \prime} \quad 83^{\circ} 42^{\prime} 33^{\prime \prime}$

Hazel Creek copper mine SF-97-SS-1 Thunderhead

$35^{\circ} 30^{\prime} 8^{\prime \prime}$

$83^{\circ} 42^{\prime} 35^{\prime \prime}$

Mountain
Date sampled Description

Pyrite \%Fines

20-Jun-97 Little Fork, a few hundred meters below Hazel Creek mine workings

Sugar Fork at main road (turnoff to mine access), just above 19 17 
Table ESM 3. Stream sediment chemistry.

\begin{tabular}{|c|c|c|c|c|c|c|c|c|c|c|c|c|c|c|c|c|c|c|c|c|}
\hline Locality & Sample No. & Element & $\mathrm{Al}$ & $\mathrm{Ca}$ & $\mathrm{Fe}$ & $\mathrm{K}$ & $\mathrm{Mg}$ & $\mathrm{Na}$ & $\mathrm{P}$ & $\mathrm{Ti}$ & $\mathrm{Ag}$ & As & As & $\mathrm{Au}$ & $\mathrm{Au}$ & $\mathrm{Ba}$ & $\mathrm{Be}$ & $\mathrm{Bi}$ & $\mathrm{Cd}$ & $\mathrm{Ce}$ \\
\hline & & Units & $\%$ & $\%$ & $\%$ & $\%$ & $\%$ & $\%$ & $\%$ & $\%$ & $\mathrm{mg} / \mathrm{kg}$ & $\mathrm{mg} / \mathrm{kg}$ & $\mathrm{mg} / \mathrm{kg}$ & $\mathrm{mg} / \mathrm{kg}$ & $\mathrm{mg} / \mathrm{kg}$ & $\mathrm{mg} / \mathrm{kg}$ & $\mathrm{mg} / \mathrm{kg}$ & $\mathrm{mg} / \mathrm{kg}$ & $\mathrm{mg} / \mathrm{kg} \mathrm{n}$ & $\mathrm{mg} / \mathrm{kg}$ \\
\hline & & Method & ICP40 I & ICP40 I & ICP40 I & ICP40 & ICP40 & ICP40 & ICP40 I & ICP40 & ICP40 & ICP40 & AAH3 & ICP40 & GFAA & ICP40 & ICP40 & ICP40 & ICP40 IC & ICP40 \\
\hline & & $\mathrm{Cl}^{1}$ & 8.4 & 4.7 & 6.2 & 1.8 & 2.8 & 2.3 & 0.1 & 0.6 & 60.08 & 2 & 2 & 0.004 & 0.004 & 390 & 2 & 0.0082 & 0.16 & 66.4 \\
\hline & & $\mathrm{TEC}^{1}$ & & & & & & & & & & 9.79 & 9.79 & & & & & & 0.99 & \\
\hline & & $\mathrm{PEC}^{1}$ & & & & & & & & & & 33 & 33 & & & & & & 4.98 & \\
\hline Alum Cave Trail area & ACT-SS-97 & & 9.2 & 0.19 & 8 & 1.4 & 0.34 & 0.84 & 0.18 & 0.16 & $<2$ & 83 & n.d. & $<8$ & n.d. & 415 & 3 & $<10$ & $<2$ & 291 \\
\hline Alum Cave Trail area & 98ACT2-SS & & 9.5 & 0.18 & 5.74 & 2.12 & 0.29 & 1 & 0.12 & 0.09 & $<2$ & 49 & 44.5 & $<8$ & 0.027 & 504 & 3 & $<50$ & $<2$ & 210 \\
\hline Alum Cave Trail area & STYX-SS & & 8.6 & 0.09 & 8.4 & 1.5 & 0.55 & 0.96 & 0.13 & 0.24 & $<2$ & 55 & n.d. & $<8$ & n.d. & 408 & 3 & $<10$ & $<2$ & 230 \\
\hline Alum Cave Trail area & HHS-R1-2-SS & & 9.0 & 0.16 & 7.2 & 1.5 & 0.33 & 0.89 & 0.16 & 0.12 & $<2$ & 70 & n.d. & $<8$ & n.d. & 406 & 3 & $<10$ & $<2$ & 255 \\
\hline Alum Cave Trail area & $N^{\prime} S^{1}-75-S S$ & & 8.7 & 0.24 & 9 & 1.5 & 0.56 & 0.94 & 0.11 & 0.37 & $<2$ & 89 & n.d. & $<8$ & n.d. & 415 & 2 & 13 & $<2$ & 231 \\
\hline Walker Camp Prong & NPS-74-SS & & 6.7 & 0.31 & 5 & 1.6 & 0.55 & 1 & 0.07 & 1.00 & $<2$ & 26 & n.d. & $<8$ & n.d. & 492 & 2 & 23 & $<2$ & 143 \\
\hline Walker Camp Prong & NPS-237-SS1 & & 7.7 & 0.15 & 5.3 & 1.7 & 0.51 & 1.4 & 0.08 & 0.60 & $<2$ & 34 & n.d. & $<8$ & n.d. & 500 & 2 & 13 & $<2$ & 111 \\
\hline Walker Camp Prong & NPS-237-SS2 & & 7.9 & 0.15 & 5.3 & 1.7 & 0.55 & 1.4 & 0.08 & 0.56 & $<2$ & 37 & n.d. & $<8$ & n.d. & 530 & 2 & 13 & $<2$ & 120 \\
\hline Beech Flats & BCFT-1-3-SS & & 6.1 & 0.11 & 4.3 & 1.76 & 0.64 & 0.315 & 0.07 & 0.82 & $<2$ & 26 & 15.3 & $<8$ & 0.015 & 527 & 3 & 62 & $<2$ & 122 \\
\hline Beech Flats & BCFT-2-3-SS & & 6.4 & 1.21 & 4.7 & 1.68 & 1.01 & 0.79 & 0.17 & 1.03 & $<2$ & 19 & 10.6 & $<8$ & 0.016 & 562 & 3 & $<50$ & $<2$ & 194 \\
\hline Beech Flats & BCFT-5-3-SS & & 1.2 & 0.02 & 0.62 & 0.03 & 0.03 & 0.01 & 0.02 & 0.30 & $<2$ & $<10$ & 9.5 & $<8$ & 0.009 & 72 & $<1$ & $<50$ & $<2$ & 27 \\
\hline Chimneys Picnic Area & NPS-66-SS & & 6.6 & 0.28 & 4 & 1.9 & 0.54 & 1.2 & 0.06 & 0.70 & $<2$ & 35 & n.d. & $<8$ & n.d. & 628 & 2 & 11 & $<2$ & 137 \\
\hline Road Prong & RP-1-SS & & 6.4 & 0.09 & 4.33 & 1.98 & 0.65 & 0.75 & 0.07 & 0.91 & $<2$ & 21 & 9 & $<8$ & 0.012 & 596 & 3 & $<50$ & $<2$ & 115 \\
\hline Road Prong & RP-3-SS & & 6.7 & 0.13 & 5.63 & 2.19 & 0.63 & 0.72 & 0.07 & 0.80 & $<2$ & 23 & 11 & $<8$ & 0.011 & 609 & 3 & 67 & $<2$ & 127 \\
\hline Road Prong & NPS-72-SS & & 5.6 & 0.14 & 3.3 & 1.9 & 0.50 & 1.1 & 0.04 & 1.10 & $<2$ & 23 & n.d. & $<8$ & n.d. & 633 & 2 & 23 & $<2$ & 160 \\
\hline Road Prong & NPS-72-3-SS & & 6.9 & 0.16 & 3.81 & 2.74 & 0.67 & 1.06 & 0.06 & 0.85 & $<2$ & 16 & 3.8 & $<8$ & 0.017 & 814 & 3 & $<50$ & $<2$ & 134 \\
\hline Road-to-Nowhere & RTN-3-3-SS & & 2.9 & 0.20 & 2.25 & 0.81 & 0.34 & 0.295 & 0.02 & 0.70 & $<2$ & $<10$ & 1.7 & $<8$ & 0.009 & 292 & 1 & $<50$ & $<2$ & 115 \\
\hline Cades Cove & CCAC-SS-97 & & 4.7 & 0.19 & 2.1 & 1.6 & 0.41 & 1.1 & 0.03 & 0.58 & $<2$ & $<10$ & n.d. & $<8$ & n.d. & 589 & 2 & $<10$ & $<2$ & 35 \\
\hline Fontana copper mine & FM-97-1-SS & & 3.1 & 0.06 & 3.2 & 0.7 & 0.23 & 0.05 & 0.02 & 0.90 & $<2$ & 10 & n.d. & $<8$ & n.d. & 230 & 1 & 18 & $<2$ & 47 \\
\hline Fontana copper mine & FM-97-2-SS & & 4.3 & 0.13 & 8 & 0.81 & 1.90 & 0.13 & 0.09 & 0.81 & 3 & 15 & n.d. & $<8$ & n.d. & 270 & 1 & 31 & $<2$ & 62 \\
\hline Fontana copper mine & FM-SS-97-3 & & 5.6 & 0.25 & 9.8 & 0.93 & 0.61 & 0.08 & 0.09 & 0.67 & $<2$ & $<10$ & n.d. & $<8$ & n.d. & 505 & 2 & 13 & $<2$ & 142 \\
\hline Fontana copper mine & FM-SS-97-4 & & 5.2 & 0.22 & 8.1 & 0.85 & 1.60 & 0.17 & 0.13 & 0.70 & $<2$ & 17 & n.d. & $<8$ & n.d. & 349 & 3 & 23 & $<2$ & 125 \\
\hline Fontana copper mine & FM-98-1-SS & & 5.3 & 0.17 & 8.9 & 1.09 & 1.48 & 0.185 & 0.07 & 0.73 & $<2$ & $<10$ & 10.3 & $<8$ & 0.026 & 428 & 3 & $<50$ & 5 & 142 \\
\hline Fontana copper mine & FM-98-2-SS & & 7.7 & 0.09 & 5.23 & 1.57 & 0.71 & 0.14 & 0.06 & 0.79 & $<2$ & $<10$ & 9.4 & $<8$ & 0.014 & 525 & 3 & $<50$ & $<2$ & 156 \\
\hline Fontana copper mine & FM-98-3-SS & & 5.9 & 0.06 & 4.24 & 1.22 & 0.55 & 0.105 & 0.04 & 0.88 & $<2$ & 13 & 1.9 & $<8$ & 0.011 & 401 & 3 & $<50$ & $<2$ & 115 \\
\hline
\end{tabular}




\begin{tabular}{|c|c|c|c|c|c|c|c|c|c|c|c|c|c|c|c|c|c|c|c|c|}
\hline Locality & Sample No. & Element & $\mathrm{Al}$ & $\mathrm{Ca}$ & $\mathrm{Fe}$ & $\mathrm{K}$ & $\mathrm{Mg}$ & $\mathrm{Na}$ & $P$ & $\mathrm{Ti}$ & $\mathrm{Ag}$ & As & As & $\mathrm{Au}$ & $\mathrm{Au}$ & $\mathrm{Ba}$ & $\mathrm{Be}$ & $\mathrm{Bi}$ & $\mathrm{Cd}$ & $\mathrm{Ce}$ \\
\hline Fontana copper mine & FM-98-4-SS & & 4.0 & 0.16 & 3.44 & 0.88 & 0.53 & 0.315 & 0.02 & 0.98 & $<2$ & 11 & 0.9 & $<8$ & 0.01 & 307 & 2 & $<50$ & $<2$ & 66 \\
\hline Hazel Creek copper mine & HCM-97-SS-1 & & 3.3 & 0.12 & 2.9 & 0.9 & 0.49 & 0.37 & 0.01 & 0.67 & $<2$ & $<10$ & n.d. & $<8$ & n.d. & 361 & 1 & 16 & $<2$ & 44 \\
\hline lazel Creek copper mine & HCM-97-SS-2 & & 4.4 & 0.18 & 4.2 & 0.94 & 1.60 & 0.37 & 0.06 & 1.00 & 2 & $<10$ & n.d. & $<8$ & n.d. & 350 & 1 & 26 & $<2$ & 58 \\
\hline lazel Creek copper mine & HCM-97-SS-3 & & 5.2 & 0.22 & 6.1 & 1 & 2.00 & 0.41 & 0.08 & 0.74 & 2 & $<10$ & n.d. & $<8$ & n.d. & 323 & 2 & 11 & 5 & 93 \\
\hline azel Creek copper mine & SF-97-SS-1 & & 3.1 & 0.09 & 2.6 & 0.76 & 0.31 & 0.45 & 0.01 & 0.75 & $<2$ & $<10$ & n.d. & $<8$ & n.d. & 293 & 1 & 17 & $<2$ & 36 \\
\hline
\end{tabular}

\begin{tabular}{|c|c|c|c|c|c|c|c|c|c|c|c|c|c|c|c|c|c|c|c|c|}
\hline Locality & Sample No. & Element & Co & $\mathrm{Cr}$ & $\mathrm{Cu}$ & Eu & $\mathrm{Ga}$ & $\mathrm{Hg}$ & Ho & La & $\mathrm{Li}$ & $\mathrm{Mn}$ & Mo & $\mathrm{Nb}$ & $\mathrm{Nd}$ & $\mathrm{Ni}$ & $\mathrm{Pb}$ & Sc & Sn & $\mathrm{Sr}$ \\
\hline & & Units & $\mathrm{mg} / \mathrm{kg} \mathrm{n}$ & $\mathrm{ng} / \mathrm{kg}$ & $\mathrm{mg} / \mathrm{kg}$ & $\mathrm{mg} / \mathrm{kg}$ & $\mathrm{mg} / \mathrm{kg}$ & $\mathrm{mg} / \mathrm{kg}$ & $\mathrm{mg} / \mathrm{kg}$ & $\mathrm{mg} / \mathrm{kg}$ & $\mathrm{g} / \mathrm{kg}$ & $\mathrm{mg} / \mathrm{kg}$ & $\mathrm{mg} / \mathrm{kg}$ & $\mathrm{mg} / \mathrm{kg}$ & $\mathrm{mg} / \mathrm{kg}$ & $\mathrm{mg} / \mathrm{kg}$ & $\mathrm{mg} / \mathrm{kg}$ & $\mathrm{mg} / \mathrm{kg}$ & $\mathrm{mg} / \mathrm{kg} \mathrm{n}$ & $\mathrm{ng} / \mathrm{kg}$ \\
\hline & & Method & ICP40 I & CP40 & ICP40 & ICP40 & ICP40 & CVAC & ICP40 & ICP40 & ICP40 & ICP40 & ICP40 & ICP40 & ICP40 & ICP40 I & ICP40 & ICP40 & ICP40 IC & CP40 \\
\hline & & $\mathrm{Cl}$ & 29 & 122 & 68 & 2 & 19 & 0.086 & 1.26 & 34.6 & 18 & 1,060 & 1.2 & 20 & 39.6 & 99 & 13 & 25 & 2 & 384 \\
\hline & & TEC (CB) & & 43.4 & 31.6 & & & 0.18 & & & & & & & & 22.7 & 35.8 & & & \\
\hline & & PEC (CB) & & 111 & 149 & & & 1.06 & & & & & & & & 48.6 & 128 & & & \\
\hline Alum Cave Trail area & ACT-SS-97 & & 62 & 47 & 76 & 3 & 18 & 0.2 & $<4$ & 90 & 85 & 2,890 & $<2$ & 10 & 81 & 38 & 34 & 15 & $<5$ & 200 \\
\hline Alum Cave Trail area & 98ACT2-SS & & 50 & 99 & 61 & 3 & 18 & 0.1 & 4 & 84 & 85 & 2,640 & 6 & 10 & 86 & 30 & 22 & 15 & $5<50$ & 217 \\
\hline Alum Cave Trail area & STYX-SS & & 42 & 36 & 72 & 4 & 14 & 0.08 & $<4$ & 104 & 79 & 3,630 & $<2$ & 6 & 100 & 26 & 27 & 15 & $<5$ & 141 \\
\hline Alum Cave Trail area & HHS-R1-2-SS & & 55 & 27 & 75 & 4 & 17 & 0.15 & $<4$ & 92 & 83 & 3,650 & $<2$ & 6 & 81 & 26 & 32 & 15 & $<5$ & 206 \\
\hline Alum Cave Trail area & NPS-75-SS & & 18 & 35 & 60 & 4 & 23 & 0.04 & $<4$ & 109 & 78 & 9,220 & $<2$ & 4 & 108 & 15 & 26 & 22 & 11 & 136 \\
\hline Walker Camp Prong & NPS-74-SS & & 20 & 30 & 25 & 2 & 13 & 0.05 & $<4$ & 71 & 42 & 4,530 & $<2$ & 24 & 63 & 15 & 45 & 13 & 84 & 104 \\
\hline Walker Camp Prong & NPS-237-SS1 & & 12 & 37 & 24 & 2 & 18 & 0.05 & $<4$ & 56 & 53 & 2,650 & $<2$ & 16 & 48 & 11 & 29 & 13 & 36 & 131 \\
\hline Walker Camp Prong & NPS-237-SS2 & & 14 & 17 & 37 & 2 & 15 & 0.05 & $<4$ & 59 & 55 & 2,430 & $<2$ & 18 & 51 & 11 & 30 & 13 & 34 & 132 \\
\hline Beech Flats & BCFT-1-3-SS & & 22 & 44 & 37 & 2 & 14 & 0.07 & $<4$ & 56 & 31 & 2,070 & 3 & 16 & 60 & 33 & 12 & 11 & $1<50$ & 55 \\
\hline Beech Flats & BCFT-2-3-SS & & 42 & 100 & 49 & 3 & 18 & 0.05 & 6 & 75 & 22 & 2,920 & 4 & 17 & 84 & 34 & 20 & 13 & $B<50$ & 135 \\
\hline Beech Flats & BCFT-5-3-SS & & $<2$ & 43 & 5 & $<2$ & $<4$ & 0.05 & $<4$ & 12 & 3 & 134 & 4 & 6 & 12 & 4 & $<4$ & 2 & $2<50$ & 26 \\
\hline Chimneys Picnic Area & NPS-66-SS & & 13 & 29 & 18 & 2 & 11 & 0.05 & $<4$ & 66 & 40 & 2,290 & $<2$ & 23 & 59 & 12 & 33 & 11 & 47 & 103 \\
\hline Road Prong & RP-1-SS & & 20 & 65 & 29 & 3 & 21 & 0.06 & $<4$ & 77 & 37 & 2,260 & 4 & 19 & 81 & 25 & 17 & 11 & $1<50$ & 77 \\
\hline Road Prong & RP-3-SS & & 46 & 88 & 33 & 2 & 7 & 0.07 & $<4$ & 63 & 36 & 5,790 & 4 & 19 & 59 & 24 & 18 & 11 & $<50$ & 79 \\
\hline Road Prong & NPS-72-SS & & 10 & 20 & 10 & 2 & 9 & 0.03 & $<4$ & 78 & 24 & 1,410 & $<2$ & 20 & 69 & 11 & 32 & 8 & 94 & 82 \\
\hline Road Prong & NPS-72-3-SS & & 13 & 78 & 18 & $<2$ & 15 & 0.04 & $<4$ & 62 & 32 & 1,310 & 4 & 23 & 62 & 22 & 8 & 11 & $1<50$ & 81 \\
\hline Road-to-Nowhere & RTN-3-3-SS & & 5 & 72 & 10 & $<2$ & 5 & $<0.02$ & $<4$ & 56 & 17 & 825 & 4 & $<4$ & 56 & 10 & $<4$ & 6 & $<50$ & 45 \\
\hline Cades Cove & CCAC-SS-97 & & 6 & 21 & 6 & $<2$ & 7 & 0.02 & $<4$ & 20 & 13 & 638 & $<2$ & 16 & 16 & 9 & 20 & 5 & 29 & 87 \\
\hline
\end{tabular}




\begin{tabular}{|c|c|c|c|c|c|c|c|c|c|c|c|c|c|c|c|c|c|c|c|c|}
\hline Locality & Sample No. & Element & Co & $\mathrm{Cr}$ & $\mathrm{Cu}$ & $\mathrm{Eu}$ & $\mathrm{Ga}$ & $\mathrm{Hg}$ & Ho & $\mathrm{La}$ & $\mathrm{Li}$ & $\mathrm{Mn}$ & Mo & $\mathrm{Nb}$ & $\mathrm{Nd}$ & $\mathrm{Ni}$ & $\mathrm{Pb}$ & Sc & Sn & $\mathrm{Sr}$ \\
\hline Fontana copper mine & FM-97-1-SS & & 15 & 20 & 19 & $<2$ & $<4$ & $<0.02$ & $<4$ & 26 & 11 & 1,520 & $<2$ & 5 & 20 & 16 & 22 & 7 & 67 & $\overline{16}$ \\
\hline Fontana copper mine & FM-97-2-SS & & 19 & 37 & 6,280 & $<2$ & 10 & 0.25 & $<4$ & 33 & 19 & 1,020 & $<2$ & 16 & 27 & 17 & 223 & 8 & 111 & 29 \\
\hline Fontana copper mine & FM-SS-97-3 & & 252 & 25 & 5,420 & 4 & 22 & 0.14 & $<4$ & 82 & 21 & 13,600 & $<2$ & 7 & 72 & 24 & 79 & 9 & 56 & 38 \\
\hline Fontana copper mine & FM-SS-97-4 & & 55 & 37 & 10,200 & 4 & 12 & 0.37 & $<4$ & 76 & 24 & 4,830 & $<2$ & 13 & 77 & 23 & 169 & 10 & 78 & 43 \\
\hline Fontana copper mine & FM-98-1-SS & & 75 & 76 & 8,900 & 3 & 5 & 0.28 & 5 & 74 & 26 & 8,140 & 8 & 12 & 83 & 23 & 157 & 9 & $<50$ & 46 \\
\hline Fontana copper mine & FM-98-2-SS & & 20 & 101 & 1,510 & 3 & 15 & 0.13 & 5 & 70 & 43 & 956 & 4 & 26 & 73 & 30 & 50 & 13 & $<50$ & 37 \\
\hline Fontana copper mine & FM-98-3-SS & & 17 & 62 & 469 & $<2$ & 20 & 0.06 & $<4$ & 53 & 36 & 852 & 3 & 24 & 54 & 27 & 16 & 11 & $<50$ & 28 \\
\hline Fontana copper mine & FM-98-4-SS & & 13 & 50 & 35 & 2 & 7 & 0.03 & $<4$ & 28 & 20 & 1,530 & 3 & 8 & 29 & 25 & $<4$ & 8 & $<50$ & 36 \\
\hline Hazel Creek copper mine & HCM-97-SS-1 & & 10 & 9 & 36 & $<2$ & 7 & $<0.02$ & $<4$ & 23 & 10 & 1,310 & $<2$ & $<4$ & 17 & 10 & 26 & 8 & 42 & 32 \\
\hline Hazel Creek copper mine & HCM-97-SS-2 & & 12 & 25 & 3,400 & $<2$ & 8 & 0.24 & $<4$ & 31 & 18 & 1,290 & $<2$ & 15 & 27 & 10 & 210 & 9 & 86 & 33 \\
\hline Hazel Creek copper mine & HCM-97-SS-3 & & 14 & 24 & 5,090 & 2 & 12 & 0.12 & $<4$ & 50 & 25 & 1,210 & $<2$ & 14 & 45 & 13 & 509 & 9 & 58 & 43 \\
\hline Hazel Creek copper mine & SF-97-SS-1 & & 6 & 9 & 10 & $<2$ & 4 & $<0.02$ & $<4$ & 22 & 13 & 1,170 & $<2$ & 5 & 18 & 8 & 22 & 6 & 50 & 39 \\
\hline
\end{tabular}

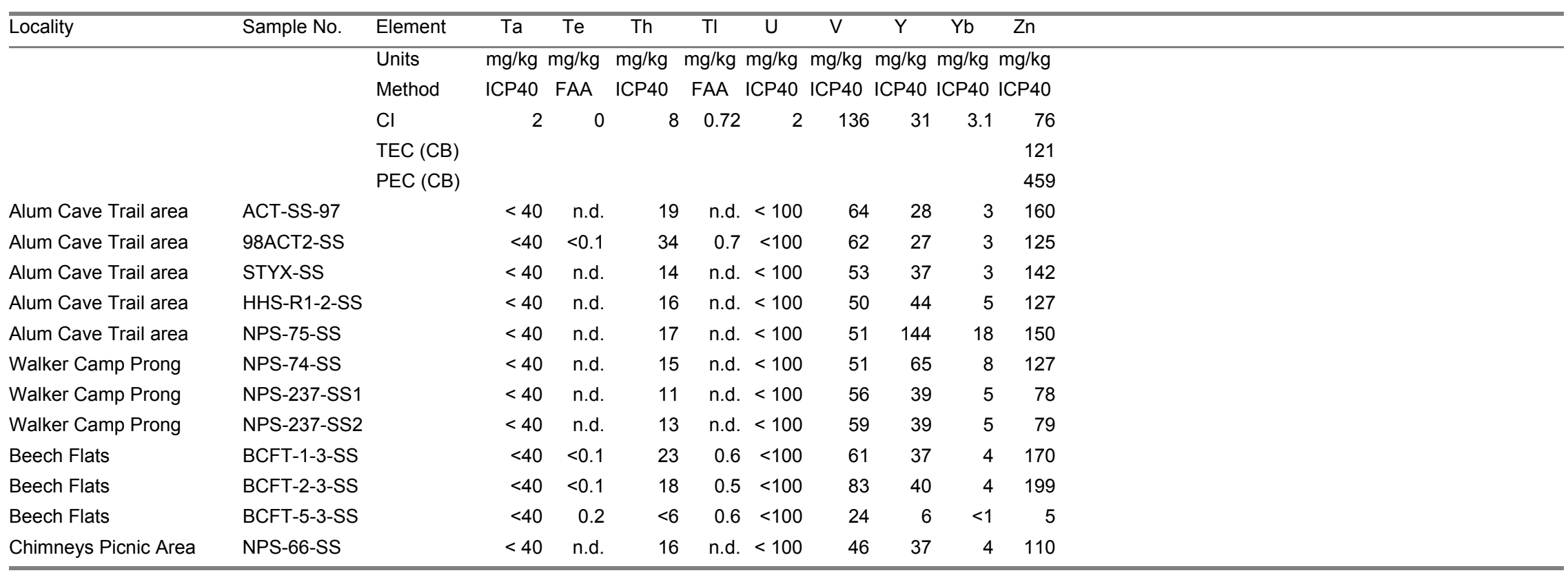




\begin{tabular}{|c|c|c|c|c|c|c|c|c|c|c|c|}
\hline \multirow{2}{*}{$\begin{array}{l}\text { Locality } \\
\text { Road Prong }\end{array}$} & \multirow{2}{*}{$\begin{array}{l}\text { Sample No. } \\
\text { RP-1-SS }\end{array}$} & \multirow[t]{2}{*}{ Element } & \multirow{2}{*}{$\begin{array}{l}\mathrm{Ta} \\
<40\end{array}$} & \multirow{2}{*}{$\begin{array}{l}\mathrm{Te} \\
<0.1\end{array}$} & \multirow{2}{*}{$\begin{array}{l}\text { Th } \\
16\end{array}$} & \multirow{2}{*}{$\begin{array}{l}\mathrm{TI} \\
0.8\end{array}$} & \multirow{2}{*}{$\begin{array}{l} \\
<100\end{array}$} & \multirow{2}{*}{$\begin{array}{l}\mathrm{V} \\
57\end{array}$} & \multirow{2}{*}{$\begin{array}{l}Y \\
54\end{array}$} & \multirow{2}{*}{$\begin{array}{r}\mathrm{Yb} \\
5\end{array}$} & \multirow{2}{*}{$\begin{array}{l}\mathrm{Zn} \\
130\end{array}$} \\
\hline & & & & & & & & & & & \\
\hline Road Prong & RP-3-SS & & $<40$ & 0.2 & 19 & 1 & $<100$ & 57 & 45 & 5 & 134 \\
\hline Road Prong & NPS-72-SS & & $<40$ & n.d. & 22 & n.d. & $<100$ & 37 & 26 & 3 & 82 \\
\hline Road Prong & NPS-72-3-SS & & $<40$ & $<0.1$ & 29 & 0.8 & $<100$ & 59 & 24 & 3 & 109 \\
\hline Road-to-Nowhere & RTN-3-3-SS & & $<40$ & $<0.1$ & 16 & $<0.1$ & $<100$ & 22 & 18 & 2 & 48 \\
\hline Cades Cove & CCAC-SS-97 & & $<40$ & n.d. & 9 & n.d. & $<100$ & 28 & 18 & 2 & 68 \\
\hline Fontana copper mine & FM-97-1-SS & & $<40$ & n.d. & $<6$ & n.d. & $<100$ & 10 & 12 & 1 & 78 \\
\hline Fontana copper mine & FM-97-2-SS & & $<40$ & n.d. & $<6$ & n.d. & $<100$ & 44 & 15 & 1 & 795 \\
\hline Fontana copper mine & FM-SS-97-3 & & $<40$ & n.d. & 9 & n.d. & $<100$ & 45 & 54 & 4 & 824 \\
\hline Fontana copper mine & FM-SS-97-4 & & $<40$ & n.d. & 7 & n.d. & $<100$ & 46 & 52 & 4 & 1,300 \\
\hline Fontana copper mine & FM-98-1-SS & & $<40$ & 0.4 & 20 & 0.4 & $<100$ & 52 & 49 & 4 & 1,380 \\
\hline Fontana copper mine & FM-98-2-SS & & $<40$ & 0.1 & 21 & 0.8 & $<100$ & 76 & 53 & 5 & 547 \\
\hline Fontana copper mine & FM-98-3-SS & & $<40$ & 0.1 & 16 & 0.4 & $<100$ & 55 & 40 & 4 & 231 \\
\hline Fontana copper mine & FM-98-4-SS & & $<40$ & $<0.1$ & 7 & 0.2 & $<100$ & 25 & 20 & 2 & 134 \\
\hline Hazel Creek copper mine & HCM-97-SS-1 & & $<40$ & n.d. & $<6$ & n.d. & $<100$ & 11 & 15 & 2 & 93 \\
\hline Hazel Creek copper mine & HCM-97-SS-2 & & $<40$ & n.d. & 6 & n.d. & $<100$ & 48 & 19 & 2 & 1,640 \\
\hline Hazel Creek copper mine & HCM-97-SS-3 & & $<40$ & n.d. & $<6$ & n.d. & $<100$ & 47 & 32 & 3 & 4,450 \\
\hline Hazel Creek copper mine & SF-97-SS-1 & & $<40$ & n.d. & $<6$ & n.d. & $<100$ & 8 & 15 & 2 & 86 \\
\hline \multirow[t]{4}{*}{${ }^{1}$ Notes } & \multicolumn{11}{|c|}{ NPS, National Park Service monitoring sites } \\
\hline & \multicolumn{11}{|c|}{ Cl, Clarke Index of crustal abundance (Fortescue 1992) } \\
\hline & \multicolumn{11}{|c|}{ TEC Consensus-based threshold effects concentration (MacDonald and others 2000) } \\
\hline & \multicolumn{11}{|c|}{ PEC Consensus-based probable effects concentration; Concentrations above PEC are shown in boldface } \\
\hline
\end{tabular}


Table ESM 4. Water sample data for stream sediment sample sites.

\begin{tabular}{|c|c|c|c|}
\hline $\begin{array}{l}\text { Sediment } \\
\text { Sample No. }\end{array}$ & Water sample & $\mathrm{pH}$ & $\begin{array}{c}\text { Specific } \\
\text { conductance } \\
(\mu \mathrm{S} / \mathrm{cm})\end{array}$ \\
\hline ACT-SS-97 & ACT-2 & 6.3 & 20.6 \\
\hline 98ACT2-SS & ACT-2-2 & 5.8 & 24.9 \\
\hline STYX-SS & STYX-1 & 5.9 & 15.5 \\
\hline HHS-R1-2-SS & HHS-R1-2 & 4.8 & 23.1 \\
\hline NPS-75-SS & NPS-75 & 5.1 & 17.5 \\
\hline NPS-74-SS & NPS-74 & 6.8 & 22 \\
\hline NPS-237-SS1 & NPS-237 & 4.7 & 19.2 \\
\hline NPS-237-SS2 & NPS-237-3 & 4.7 & 20.6 \\
\hline \multirow[t]{2}{*}{ BCFT-1-3-SS } & BCFT-1-3 & 6.3 & 24.8 \\
\hline & Site 1 & 6.4 & $15-51$ \\
\hline \multirow[t]{2}{*}{ BCFT-2-3-SS } & BCFT-2-3 & 5.8 & 34.2 \\
\hline & Site 2 & 4.7 & $59-109$ \\
\hline BCFT-5-3-SS & BCFT-5-3 & 6.2 & 30.3 \\
\hline NPS-66-SS & NPS-66 & 6.7 & 18.2 \\
\hline RP-1-SS & RPSL-1A-3 & 6.7 & 15.4 \\
\hline RP-3-SS & RPSL-3-3 & 6.4 & 15.4 \\
\hline NPS-72-SS & NPS-72 & 6.6 & 14.7 \\
\hline NPS-72-3-SS & NPS-72-3 & 7.1 & 17.3 \\
\hline RTN-3-3-SS & RTN-3-3 & 6.8 & 16.4 \\
\hline CCAC-SS-97 & CCAC-1 & 6.6 & 12.3 \\
\hline FM-97-1-SS & FM-1-3 & 6.9 & 20.3 \\
\hline FM-97-2-SS & None & & \\
\hline FM-SS-97-3 & FM-10-2 & 6.7 & 63.9 \\
\hline FM-SS-97-4 & FM-11-2 & 6.7 & 19.5 \\
\hline FM-98-1-SS & FM-10-3 & 6.3 & 147.5 \\
\hline FM-98-2-SS & FM-11-3 & 6.5 & 34.8 \\
\hline FM-98-3-SS & FM-11-3 & 6.5 & 34.8 \\
\hline FM-98-4-SS & FM-12-3 & 6.8 & 23.3 \\
\hline HCM-97-SS-1 & None & & \\
\hline HCM-97-SS-2 & HCM-3-2 & 6.5 & 16.2 \\
\hline HCM-97-SS-3 & None & & \\
\hline SF-97-SS-1 & None & & \\
\hline
\end{tabular}

${ }^{1}$ Water data from Seal and others (1997) and Seal (written communication, 2000). 